\title{
Uzamsal Referans Çerçeveleri ve Türkçedeki Görünümleri Üzerine Bir İnceleme*
}

\author{
Ata Atak ${ }^{1}$, Gülsün Leyla Uzun ${ }^{2}$ \\ ORCID ID: ${ }^{10000-0002-0897-8287, ~}{ }^{20000-0002-9070-791 X ~}$ \\ ${ }^{1}$ Dokuz Eylül Üniversitesi, Dil Eğitimi Uygulama ve Araşttrma Merkezi, Şehitler Caddesi No:12 \\ Alsancak, Konak/İzmir \\ ${ }^{2}$ Ankara Üniversitesi, Dil ve Tarih-Coğrafya Fakültesi, Dilbilim Bölümü, Sihhiye-Ankara \\ Iata.atak@deu.edu.tr, ${ }^{2}$ gulsunleylauzun@gmail.com
}

(Received 8 January 2019; accepted 2 May 2019)

ÖZ: Bu çalıșma uzamsal referans çerçeveleri üzerine Türkçeden bakıldığında ne tür görünümlere erişilebileceği sorusundan hareketle yapılmıştır. Türkçe için kullanılan uzamsal referans çerçevelerini tespit etmek amacıyla gerçekleştirilen uygulamada, konumlanış ilişkisi aktaran ikili nesne düzenlemelerinden oluşan dört farklı üretim görevi (production task) 40 kadın ve 40 erkek olmak üzere toplam 80 katılımcı tarafından yerine getirilmiştir. Çalışma, bu uygulamada katılımcıların yerine getirdiği üretim görevlerinden elde edilen verilere dayalı bir tartışma sunmaktadır.

Çalışmanın öne çıkardığı bulguların ilki Türkçede iki nesne arasındaki konumlanış ilişkisini aktarmak amacıyla içsel (intrinsic) ve göreli (relative) referans çerçevelerinin kullanılıyor oluşudur. Öte yandan, konumlanan ile konumlayan olan nesnelerin özelliklerinin uzamsal referans çerçevesi seçimini Türkçede de doğrudan etkilemekte olduğu çalışmanın bir diğer bulgusunu oluşturmuştur. Öyle ki, kullanım sıklıkları, konumlanan ve konumlayan olan nesnelerin özelliklerine göre ve nesne düzenlemelerine göre farkl1lık göstermektedir. $\mathrm{Bu}$ çalışmanın araştırma soruları çerçevesinde cinsiyetin uzamsal referans çerçevesi seçiminde bir değişken olmadığı saptanmıştır. Bunun yanında fen bilimleri ile sosyal bilimlerden gelen katılımcılar arasında göreli referans çerçevesi kullanımı açısından anlamlı bir fark olmazken içsel referans çerçevesi kullanma eğilimi fen bilimlerinden gelen katılımcılarda daha fazladir.

Anahtar sözcükler: uzam, uzamsal dil, uzamsal referans çerçeveleri

\section{Spatial Frames of Reference and an Investigation of Their Representations in Turkish}

ABSTRACT: This study was carried out to answer what kind of representations in Turkish could be obtained on spatial frames of reference. In the experiment which was conducted to determine spatial frames of reference used in Turkish,

\footnotetext{
* Bu makale "Türkçede Uzamsal Dilin Konumlanış Açısından İncelenmesi" başlıklı doktora tezinden üretilmiştir ve "32. Ulusal Dilbilim Kurultayı"nda sunulan sözlü bildirinin genișletilmiş biçimidir.
} 
four different production tasks consisting of two object arrangements which indicate localization were done by total 80 participants 40 of whom were female and 40 of whom were male. This study presents a discussion based on the data which were obtained from the production tasks by the participants.

The first highlighted finding of this study is that intrinsic and relative frames of reference are used to convey the relation of localization between two objects in Turkish. On the other hand, the features of objects which are figure and ground affect directly the selection of spatial frames of reference in Turkish is the other finding of this study. So much so that frequency of their usage varies according to the features of objects which are figure and ground and their arrangements. It was determined that gender was not variable in the selection of spatial frames of reference within the scope of research questions of this study. Besides that, there was not a significant difference in terms of relative frame of reference usage between the participants from social science and physical science, tendency of intrinsic frame of reference usage was higher in the participants from physical science.

Key words: space, spatial language, spatial frames of reference

\section{Giriş}

Bu çalışmada uzamsal referans çerçeveleri üzerine odaklanılmaktadır. Çalışma, konumlayan temel alınarak belirlenen arama alanı (search domain) kullanılarak bir uzamsal ilişkide konumlananı (figure) konumlayanla (ground) ilişkisine göre konumlandırmak üzere kullanılan uzamsal referans çerçevelerinin Türkçedeki görünümleri üzerine bir tartışma sunmayı amaçlamaktadır.

$\mathrm{Bu}$ amaç doğrultusunda aşağıdaki araştırma sorularına yanıt aranacaktır:

1. Türkçede Levinson $(1996 ; 2003)$ tarafindan diller için belirlenen üç uzamsal referans çerçevesinden hangileri kullanılmaktadır?

2. Konumlanan ile konumlayan olan nesnelerin özellikleri uzamsal referans çerçevesi seçimini nasıl etkilemektedir?

3. Uzamsal referans çerçevesi seçiminde cinsiyet bir değişken midir?

4. Uzamsal referans çerçevesi seçiminde fen bilimleri ile sosyal bilimler arasında anlamlı bir fark var mıdır?

Çalışmanın izleyen bölümlerinde önce araştırma sorularımızı oluşturmakta rol yüklenen ilgili kuramsal çerçeve sunulacak; ardından katılımcılar ile gerçekleştirilen uygulamanın ve veri toplama ile etiketleme sürecinin ayrıntılarıyla sunulacağı yöntem bilgilerine değinilecektir. Yöntem bölümü sonrasında bulgularımız ortaya koyulacak ve bu bulgulardan yola çıkarak oluşturduğumuz vargılara yer verilecektir. 


\section{Kuramsal Çerçeve}

Referans çerçevesi kavramı, nesnelerin diğer nesnelere göre konumlanışlarını hesaplamak ve belirlemek için onların ölçülmüş bazı özelliklerine göre bir konumlayıcı dizgesi (coordinate system) kurmak üzere kullanılan birim ya da birimler düzenine gönderimde bulunur (bkz. Levinson, 2003; Majid vd., 2004). Bu kavram, Gestalt'ın 1920'lerdeki algı kuramlarından kaynağını alan bir içeriğe sahiptir. Öyle ki, değişen referans çerçeveleri bir konumlayan nesnenin merkeze alınmasıyla saptanan arama alanı aracılığıyla konumlananı bir konumlayanla ilişkisine bağlı olarak farklı biçimlerde konumlandırmaya olanak veren konumlanış stratejilerinin kullanılmasına olanak verir.

(1) a. Araba alışveriş merkezinin önünde.

b. Araba alışveriş merkezinin kuzeyinde.

Örnek 1'de görüldüğü gibi konumlanan olan "araba" konumlayan olan "alışveriş merkezi" aracılı̆̆ıyla farklı biçimlerde konumlandırılmıştır. Alışveriş merkezinin arama alanını yansıtmak için değişen referans çerçevelerinin sunduğu olanakla farklı stratejiler kullanılmıştır.

Levinson (1996; 2003) dikey eksen (alt/üst) için algısal ipuçlarının her zaman çakışmasa da büyük çoğunlukla birleştiğini ve bize bir eksene ait iyi bir evrensel çözüm sağladığını iddia etmektedir. Ancak, yatay eksenin (sağ/sol/yan) betimlenmesi için basit bir çözüm yoktur ve diller bu düzlemde çok farklılaşmaktadır.

Levinson (1996; 2003) yatay uzamsal yönlerin betimlenmesi sorununu çözmek için diller açısından üç temel referans çerçevesi sunmaktadır:

1. İçsel (intrinsic, object-centered) referans çerçevesi

2. Göreli (relative, deictic, viewer-centered) referans çerçevesi

3. Mutlak (absolute, extrinsic, environment-centered) referans çerçevesi

\section{1 İ̧sel Referans Çerçevesi}

İçsel referans çerçevesi, nesne-merkezli bir konumlayıcı dizgesini içermektedir. $\mathrm{Bu}$ konumlayıcılar, kendinden var olan özellikler (inherent features) yani konumlayan olarak kullanılan nesnenin tarafları ya da kenarları aracılığı ile belirlenir (Levinson, 2003).

İçsel referans çerçevesinde konumlanan, konumlayanın merkezinden başlayan konumlayanın adlandırılmış tarafi (named facet) boyunca uzanan bir arama alanında konumlandırılır (Levinson, 1996).

(2) Araba okulun önünde. 
Örnek 2'de araba, okulun “ön” olarak adlandırılmış, belirlenmiş tarafından yansıtılan bir arama alanı içerisinde konumlandırılmıştır.

Majid vd.'ye (2004) göre içsel referans çerçevesi için bilişsel dizge, nesneleri temel parçalara bölmek zorundadır. $\mathrm{Bu}$ parçalara bölme eylemi gerçekleştirilirken diller farklı ölçütler kullanmaktadır. Örneğin İngilizce için belirlenen ölçütler şöyledir:

1. Üst, alt ve yan bölümlerini belirleyen yönlendirilmiş bir şablon.

2. İşlevsel ölçüt: girdiğin taraf binanın önü, izlediğin taraf televizyonun önü gibi.

Levinson'a (2003) göre dildeki özellik ne olursa olsun, içsel referans çerçevesi temel olarak nesnenin şekil, kabul edilmiş yön, hareket ediş biçimi ve kullanımı gibi kavramsal özelliklerine dayanır.

Sağ ve sol boyutunun bakışımsızlığından dolayı, nesnelerin içsel sağ ve sola sahip olmaları durumu nadir olarak ortaya çıkmaktadır (Vandeloise, 1986). Bu bakışımsızlık ve dikey boyuttaki yerçekimi baskınlığından dolayı içsel önün belirlenmesi önemli bir başlangıç noktası oluşturmaktadır. 'Ön' tarafı bulmak hazır zıtlıklar dizgesi için bir çapa (anchor) işlevi görmektedir. Bir defa içsel ön belirlenirse bu çapadan hareketle arka ve sağ-sol taraflar da belirlenebilmektedir (Retz-Schmidt, 1988).

Arama alanının boyutu genişledikçe farklı türde ifadeler mümkün hale gelmektedir. Bazı diller konumlanan ve konumlayanın temas içinde olmasını ya da görsel olarak sürekli olmasını gerektirirken diğerleri büyük arama alanlarının yansımasına izin vermektedir.

\subsection{Göreli Referans Çerçevesi}

Konumlayanın içsel bir önü yoksa ya da referans çerçevesi belirlemek için içsel yönü kullanılmıorsa ön, bağlam kullanılarak verilir ya da ona yansıtılır (Miller \& Johnson-Laird, 1976; Vandeloise, 1986). Miller \& Johnson-Laird (1976) bunu geçici ön (accidental front) olarak adlandırmaktadır. Bir nesne çevresindeki diğer nesneler aracıllğılyla geçici bir ön edinebilir. Örneğin bir evin önündeki ağacın geçici önü, sokağa baktığı taraftır.

Konumlayıcı oluşturmada bağlamın kullanılması işleminde bir görüş açısı (viewpoint) (algılayanın konumu tarafından verilen) ve bu açı dışında bir konumlanan ve konumlayan üçlemesi öngörülür. Görüş açısı, aşağıda yer alan Örnek 3'tekine benzer biçimde konumlanan ve konumlayandan oluşan üç noktanın üçgenleştirilmesini sağlar ve konumlanan ile konumlayana yönleri atamak için bu açıdaki konumlayıcıları kullanır. Bu yolla göreli referans çerçevesinin kullanımı gerçekleştirilmektedir. Örnekte konumlanan olan 'top' 
konumlayan olan 'ağaç'ın, algılayanın görüş açısına göre 'solunda' konumlandırılmıştır.

(3) Top ağacın solunda.

Majid vd.'ye (2004) göre göreli ile içsel referans çerçevesi arasında sıkı bir bağ vardır; içsel referans çerçevesi olmadan göreli referans çerçevesine sahip olmak mümkün değildir. Göreli dizgesi olan dillerin en azından bazı aynı terimleri kullanan içsel dizgeleri de bulunmaktadır. Bu özellik 'sol, sağ, ön, arka' uzamsal terimleri için bazen anlam karışıklığına yol açmaktadır. Bu nedenle, olası karmaşanın engellenebilmesi için görüş açısının açıkça belirtilmesi (buradan, şurada vb.) ya da tümceyi sadece içsel olarak yorumlanacak biçimde düzenlemek çözüm sunabilmektedir (Hill, 1982; Vandeloise, 1986).

(4) C'est ma soeur à gauche de Jean. (göreli)

(Jean'ın solundaki benim kız kardeşim.) (göreli)

C'est ma soeur à la gauche de Jean. (içsel)

(Jean'ın sol yanındaki benim kız kardeşim.) (içsel) (Hill, 1982)

Örnek 4'te görüldüğü gibi Fransızca göreli ve içsel referans çerçeveleri arasındaki anlam karmaşasını belirli tanımlık kullanarak (la) sözdizimsel olarak önleyebilmektedir.

İçsel dizge, insanın uzama dair dilsel betimlemelerinde göreli dizgeye göre daha temeldir. Görüş açısından konumlayana yönelen konumlayıcılarda göreli dizge, içsel referans çerçevesinin genişletilmiş biçimini kullanır. Görüş açısından konumlayıcılar yansıtıldığında konumlayana taklit edilmiş-içsel (pseudointrinsic) yüzeyler atanır. Örnek 3'te olduğu gibi ağaçların önleri, arkaları ve yanları varmış gibi konuşuruz.

\subsection{Mutlak Referans Çerçevesi}

Mutlak referans çerçevesinde uzamsal ilişki, konumlanan - konumlayan düzlemine dişsal olan, sabit yön biçiminde kavramlaştırılmaktadır (Haviland, 1993; 1998; Levinson, 1996; 2003; Pederson vd., 1998). Mutlak dizge, yer çekimi tarafından belirlenen sabit yönlerden oluşur. Birçok dil, yatay eksende geniş, hatta bazıları özel bir mutlak referans çerçevesi kullanır. Bu diller sabit yönleri keyfi olarak ana yönler olarak sabitlemektedir (Levinson, 2003).

(5) 'Kaşık kupanın önünde' yerine 'Kaşık kupanın kuzeyinde'

Örnek 5'te konumlanan olan kaşık, konumlayan olan kupadan yansıyan ve keyfi biçimde kültürel olarak kabul gören yön olan 'kuzeye' göre konumlandırılmıştır. 
$\mathrm{Bu}$ nedenle, masa-üstü (table-top) uzamdan coğrafi uzama kadar bütün durumlarda mutlak referans çerçevesi kullanımı hesaplamalar gerektirir (Majid vd., 2004). Her zaman ve her konumlanışta uzlaşımsal sabit yönleri bilmek gerekir. Örneğin Avusturalya'da kullanılan yerel bir dil olan Guugu Yimithirrde yerel 'kuzey' yaklaşık olarak K017º yönündedir (Haviland, 1993; 1998). Meksika'da kullanılan bir Maya dili olan Tzeltalde ise 'uphill' (yokuş yukarı) ve 'downhill' (yokuş aşağı) terimleri kullanılır. 'Yokuş yukarı' yaklaşık K345' yönünde yer alır (Brown \& Levinson, 2000).

Mutlak referans çerçevesinde kullanılan uzamsal terimlerin temelinde farklı mantıksal nedenler bulunmaktadır:

1. Hepsi kültürel sabit soyutlamalar olan keyfi sabit yönler (Levinson, 1998)

a. Güneşin mevsimsel hareketleri

b. Hakim rüzgar yönleri

c. Önemli nehirlerin suyunun çekilmesi

d. Arazinin eğimi

e. Ana yönler

2. Konuşma katılımcıları ve konumlanan - konumlayan dışında bir bilgi (Pederson vd., 1998).

İçsel dizge; nesne türlerinin çeşitliliği, yüzeylerin adlandırılmasını sağlayan nesnelerin asimetrilerindeki farklı dereceler ve özelliksiz nesneler problemleriyle karşılaşır. Göreli dizge; sağ/sol ayrımını öğrenmede yaşanan psikolojik zorluklar, ikincil konumlayıcıların haritalandırılmasında yaşanan karmaşıklıklarla karşılaşır. Dilsel ifadeler içsel olanlardan türetildiği için referans çerçeveleri arasında anlam karmaşaları ortaya çıkmaktadır. Mutlak dizgenin yükümlülüğü içsel ve göreli dizgeden farklı olarak mantık ve psikoloji kaynaklı değişkenlere bağlı değildir (Levinson, 2003). Bu değişkenler, sadece şu bilişsel ek yükleri yüklemektedir: Ana yönlerin hesaplanması için sabit art bilgi ve konuşucunun bulunduğu noktadan bir keyfi noktayı belirlemek için kullanılan hesaplama dizgesi.

Majid vd. (2004) uzamsal referans çerçevesi seçimlerine göre bazı dilleri Tablo 1'deki gibi sınıflandırmaktadır: 
Tablo 1. Uzamsal referans çerçevelerin diller arası görünümleri (Majid vd., 2004: 112)

\begin{tabular}{|c|c|c|c|c|c|}
\hline \multirow[t]{2}{*}{ Dil } & \multirow[t]{2}{*}{ Dil Ailesi } & \multirow[t]{2}{*}{ Ülke } & \multicolumn{3}{|c|}{ Uzamsal Referans Çerçevesi } \\
\hline & & & İçsel & Göreli & Mutlak \\
\hline Arrernte & Pama Nyungan & Avusturalya & $\mathrm{x}$ & & $\mathrm{X}$ \\
\hline Balinese & Avustronezya & Endonezya & $\mathrm{x}$ & $\mathrm{x}$ & $X$ \\
\hline Belhare & Tibet-Burma & Nepal & $\mathrm{x}$ & $\mathrm{x}$ & $\mathrm{X}$ \\
\hline Flemenkçe & Hint-Avrupa & Hollanda & $\mathrm{x}$ & $\mathrm{X}$ & $(\mathrm{x})$ \\
\hline İngilizce & Hint-Avrupa & $\begin{array}{l}\text { İngiltere, } \\
\text { Amerika vd. }\end{array}$ & $\mathrm{x}$ & $\mathrm{X}$ & (x) \\
\hline Ewe & Nijer-Kongo & Gana & $\mathrm{X}$ & $\mathrm{X}$ & $\mathrm{X}$ \\
\hline $\begin{array}{l}\text { Guugu } \\
\text { Yimithirr }\end{array}$ & Pama Nyungan & Avusturalya & & & $\mathrm{X}$ \\
\hline Hai//om & Khoisan & Namibya & $\mathrm{x}$ & $(\mathrm{x})$ & $\mathrm{X}$ \\
\hline Jaminjung & Jaminjungan & Avusturalya & $\mathrm{X}$ & $(\mathrm{x})$ & (x) \\
\hline Japonca & Japonca & Japonya & $\mathrm{x}$ & $X$ & (x) \\
\hline Kgalagadi & Bantu & Botsvana & $\mathrm{X}$ & $\mathrm{X}$ & $\mathrm{X}$ \\
\hline Kilivia & Avustronezya & $\begin{array}{l}\text { Papua Yeni } \\
\text { Gine }\end{array}$ & $\mathrm{X}$ & $X$ & $\mathrm{X}$ \\
\hline Longgu & Avustronezya & $\begin{array}{l}\text { Solomon } \\
\text { Adaları }\end{array}$ & $\mathrm{x}$ & (x) & $\mathrm{X}$ \\
\hline Mopan & Maya & Belize & $\mathrm{X}$ & & (x) \\
\hline Tamil & Dravidian & Hindistan & $\mathrm{x}$ & $\mathrm{X}$ & $\mathrm{X}$ \\
\hline Tiriyó & Cariban & Brezilya & $\mathrm{X}$ & $\mathrm{X}$ & $\mathrm{X}$ \\
\hline Totonac & Totonacan & Meksika & $\mathrm{X}$ & & (x) \\
\hline Tzeltal & Maya & Meksika & $\mathrm{x}$ & & $\mathrm{X}$ \\
\hline Warwa & Nyulnyulan & Avusturalya & $\mathrm{x}$ & & $\mathrm{X}$ \\
\hline Yukatek & Maya & Meksika & $\mathrm{X}$ & $\mathrm{X}$ & $\mathrm{x}$ \\
\hline
\end{tabular}

$\mathrm{X}$ : Bu referans çerçevesi o dilde baskın olarak kullanılmaktadır.

$\mathrm{x}$ : Bu referans çerçevesi o dilde kullanılmaktadır.

(x): $\mathrm{Bu}$ referans çerçevesi o dilde çok sınırlı kullanılmaktadır. (masa-üstü uzamda kullanılmamaktadır.)

Tablo 1'de yer alan uzamsal referans çerçevelerinin farklı dillerdeki tercih edilme derecelerine bakıldığında, mutlak referans çerçevesinin Tablo 1'de yer verilen dillerin hepsinde kullanıldığı; oldukça benzer bir biçimde içsel referans çerçevesinin de Guguu Yimithirr hariç tüm diğer dillerde kullanımının olduğu görülmektedir. $\mathrm{Bu}$ üç referans çerçevesi arasında göreli referans çerçevesi diğerlerine göre daha az kullanılmaktadır. Her üç referans çerçevesinin de kullanıldığı dillerde baskın olan referans çerçevesi çeşitlilik göstermektedir. 


\subsection{Türkçe Üzerine Yapılan Çalışmalar}

Uzamsal dil Türkçe açısından çeşitli açılardan ele alınsa da uzamsal referans çerçevelerinin Türkçedeki görünümlerini test eden çalışma sayısı oldukça sınırlıdır. Johnston \& Slobin (1979) uzamsal dilin edinimini, Özyürek (2000) Türkçe ve İngilizce söylemdeki uzamsal kavramlaştırmaları, Sümer vd. (2013; 2016) ise Türkçede ve Türk İşaret Dilinde uzamsal dilin edinimini ele almıştır.

Arık (2003) Türkçede ve Türk İşaret Dilinde uzamsal görünümleri beş farklı özellik açısından ele almıştır: farklı yüklemlerin kullanımı, konumlanış ifade eden özgül dilsel biçimler, ifadede perspektif alma, ifadede kullanılan uzamsal referans çerçeveleri ve jestler. Bu çalışmada uzamsal referans çerçevesi olarak Türkçe konuşucuları sıklıkla içsel referans çerçevesini tercih ederken Türk İşaret Dili kullanıcıları içsel/göreli referans çerçevesini tercih etmiştir.

\section{Yöntem}

\subsection{Araştırma Grubu}

$\mathrm{Bu}$ çalışmanın araştırma grubunu, anadili Türkçe olan ve yabancı dil olarak İngilizce öğrenen 17-30 yaş arasındaki 53 kadın ve 43 erkek olmak üzere toplam 96 gönüllü katılımcı oluşturmaktadır. Bu katılımcılar arasından görevleri yarım bırakanlar ya da eksik tamamlayanlar çıkartılmış ve cinsiyet değişkeni açısından dengeleme sağlanarak 40 kadın ve 40 erkek olmak üzere toplam 80 katılımcı çalışmanın çözümleme aşamasına dahil edilmiştir.

Fen bilimleri ve sosyal bilimler olmak üzere farklı alanlardan seçilen katılımcılar; Çevre Mühendisliği, Moleküler Biyoloji ve Genetik, Biyoloji, İngilizce Öğretmenliği ile İngiliz Dili ve Edebiyatı bölümlerinde öğrenim görmekte olan lisans öğrencileridir. Katılımcıların bölümlere göre dağılımı Grafik 1'deki gibidir: 
Grafik 1. Katılımcıların ögrrenim gördükleri bölümlere göre dağılımı

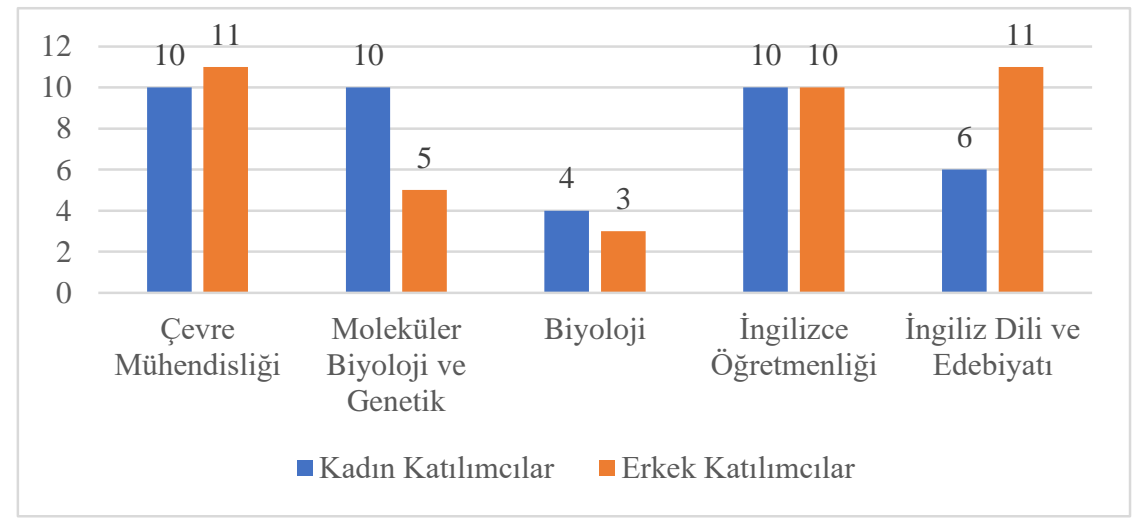

Grafik 1'de görüldüğü gibi toplam 43 katılımcı fen bilimlerinden, toplam 37 katılımcı da sosyal bilimlerdendir. Kadın katılımcıların yaş ortalaması 19 iken erkek katılımcıların yaş ortalaması 19,125'tir.

\subsection{Veri Toplama Aract}

Bu çalışmada, Türkçe için hangi dilsel özelliklerin hangi uzamsal özelliklerle bağlantılı olduğunu test etmek ve uzamda konumlanış aktarmak için kullanılan uzamsal terimleri saptamak amacıyla bir uygulama oluşturulmuştur. Oluşturulan uygulamada Carlson \& Hill'de (2007) yer alan üretim görevleri kullanılmıştır. Çalışmamızda sınırlı bir setten yapılan üretim görevi tercih edilmiştir. Konumlanan ve konumlayan olan nesneler araştırmacı tarafından belirlenerek katılımcılara verilmiştir. Katılımcılardan konumlananın konumlayana göre konumlanışını içeren tümceleri tamamlamaları istenmiştir.

Uygulama, toplam 4 farklı üretim görevinden oluşmaktadır. Görevlerdeki konumlanan ile konumlayan ilişkileri şu biçimde düzenlenmiştir:

\subsubsection{Görev 1}

Konumlayanın bir kare, konumlananın ise bir daire olduğu ilk görevde iki nesne 7 X 7 bir çerçevenin içine yerleştirilmiştir. Çerçevenin hücreleri $2 \mathrm{~cm}$ X $2 \mathrm{~cm}$ genişlikten oluşmaktadır. Çerçevenin toplam boyutu $14 \mathrm{~cm}$ X $14 \mathrm{~cm}$ genişliğinden oluşmaktadır. Konumlayan olan kare, çerçevenin 3 X 3 hücrelik kısmında merkezde yer almaktadır ve $6 \mathrm{~cm}$ X $6 \mathrm{~cm}$ genişliğindedir. Konumlayanın yeri her zaman sabit olup $2 \mathrm{~cm} X 2 \mathrm{~cm}$ genişliğinde konumlanan olan daire, konumlayanın çevresindeki 40 farklı hücreyi dolaşmaktadır. Bu görevde katılımcılar 40 farklı sahne görüntülemiştir. Uygulama aşamasında bu 
çerçeve kaldırılmış olup katılımcılar yalnızca konumlayan olan kareyi ve onun etrafında dolaşan konumlanan olan daireyi görüntülemiştir.

Şekil 1. Görev 1'in konumlanan - konumlayan düzenlemesi
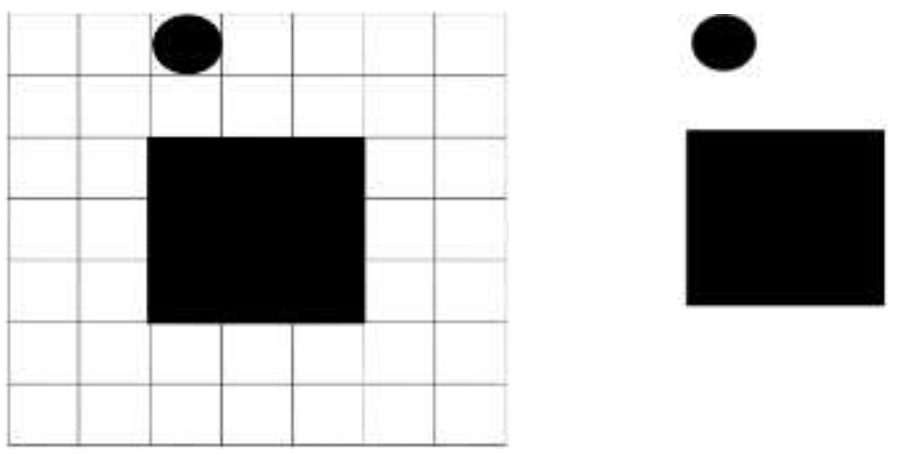

Katılımcilardan her sahneye bakmaları ve konumlanan ile konumlayan arasındaki ilişkiyi verilen tümcelerdeki boşlukları doldurarak betimlemeleri istenmiştir.

(6) "Daire karenin

\subsubsection{Görev 2}

Konumlayanın suda yüzen bir kayık, konumlananın ise uçan bir kuş ya da yüzen bir balık olduğu ikinci görevde iki nesne $6 \times 7$ hücrelik bir çerçeve içine yerleştirilmiştir. Çerçevenin hücreleri $2 \mathrm{~cm}$ X $2 \mathrm{~cm}$ genişliğindedir. Çerçevenin toplam boyutu $12 \mathrm{~cm} \mathrm{X} 14 \mathrm{~cm}$ genişliğinden oluşmaktadır. Konumlayan olan kayık, çerçevenin 2 X 3 hücrelik kısmında merkezde yer almaktadır ve $4 \mathrm{~cm} \mathrm{X}$ $6 \mathrm{~cm}$ genişliğindedir. Konumlayanın yeri her zaman sabit olup $2 \mathrm{~cm}$ X $2 \mathrm{~cm}$ genişliğinde konumlanan olan kuş ya da balık, konumlayanın çevresindeki 36 farklı hücreyi dolaşmaktadır. $\mathrm{Bu}$ görevde katılımcılar 36 farklı sahne görüntülemişlerdir. Uygulama aşamasında bu çerçeve kaldırılmış olup katılımcılar yalnızca konumlayan olan kayığı ve onun etrafında dolaşan konumlanan olan kuş ya da balığı görüntülemiştir. 
Şekil 2. Görev 2'nin konumlanan - konumlayan düzenlemesi
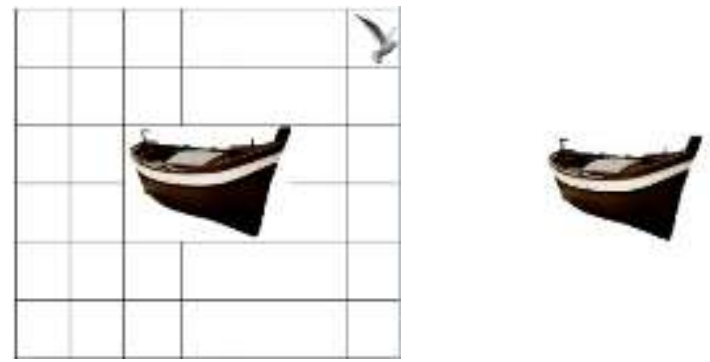

Katılımcılardan her sahneye bakmaları ve konumlanan ile konumlayan arasındaki ilişkiyi verilen tümcelerdeki boşlukları doldurarak betimlemeleri istenmiştir.

(7) “Kuş kayı̆̆ıı

"Balık kayığın

\subsubsection{Görev 3}

Konumlayanın ayakta yan duran bir adam, konumlananın ise bir top olduğu üçüncü görevde iki nesne $8 \times 6$ hücrelik bir çerçeve içine yerleştirilmiştir. Çerçevenin hücreleri $2 \mathrm{~cm} \mathrm{X} 2 \mathrm{~cm}$ genişliğinde olup toplam boyutu $16 \mathrm{~cm} \mathrm{X} 12$ $\mathrm{cm}$ genişliğinden oluşmaktadır. Konumlayan olan adam, çerçevenin $6 \mathrm{X} 2$ hücrelik kısmında merkezde yer almaktadır ve $12 \mathrm{~cm} \mathrm{X} 4 \mathrm{~cm}$ genişliğindedir. Konumlayanın yeri her zaman sabit olup $2 \mathrm{~cm} X 2 \mathrm{~cm}$ genişliğinde konumlanan olan top, konumlayanın çevresindeki 36 farklı hücreyi dolaşmaktadır. Bu görevde katılımcılar 36 farklı sahne görüntülemişlerdir. Uygulama aşamasında bu çerçeve kaldırılmış olup katılımcılar yalnızca konumlayan olan adamı ve onun etrafinda dolaşan konumlanan olan topu görüntülemiştir.

Şekil 3. Görev 3 'ün konumlanan - konumlayan düzenlemesi
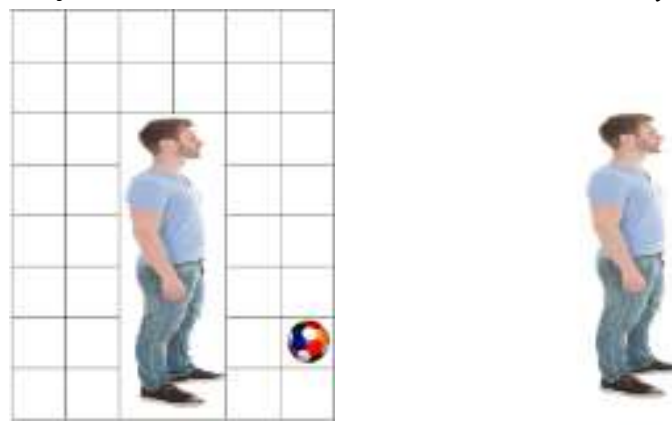
Katılımcılardan her sahneye bakmaları ve konumlanan ile konumlayan arasındaki ilişkiyi verilen tümcelerdeki boşlukları doldurarak betimlemeleri istenmiştir.

(8) “Top adamin

\subsubsection{Görev 4}

Konumlayanın bir ayaklı dolap, konumlananın ise bir top olduğu dördüncü görevde iki nesne 9 X 6 bir çerçevenin içine yerleştirilmiştir. Çerçevenin hücreleri $2 \mathrm{~cm}$ X $2 \mathrm{~cm}$ genişlikten oluşmaktadır. Çerçevenin toplam boyutu 18 $\mathrm{cm}$ X $12 \mathrm{~cm}$ genişliğinden oluşmaktadır. Konumlayan olan dolap, çerçevenin 7 X 4 hücrelik kısmında merkezde yer almaktadır ve $14 \mathrm{~cm}$ X $8 \mathrm{~cm}$ genişliğindedir. Konumlayanın yeri her zaman sabit olup $2 \mathrm{~cm}$ X $2 \mathrm{~cm}$ genişliğinde konumlanan olan top, konumlayanın çevresindeki 30 farklı hücreyi dolaşmaktadır. $\mathrm{Bu}$ görevde katılımcılar 30 farklı sahne görüntülemiştir. Uygulama aşamasında bu çerçeve kaldırılmış olup katılımcılar yalnızca konumlayan olan dolabı ve onun etrafında dolaşan konumlanan olan topu görüntülemiştir.

Şekil 4. Görev 4'ün konumlayan - konumlanan düzenlemesi
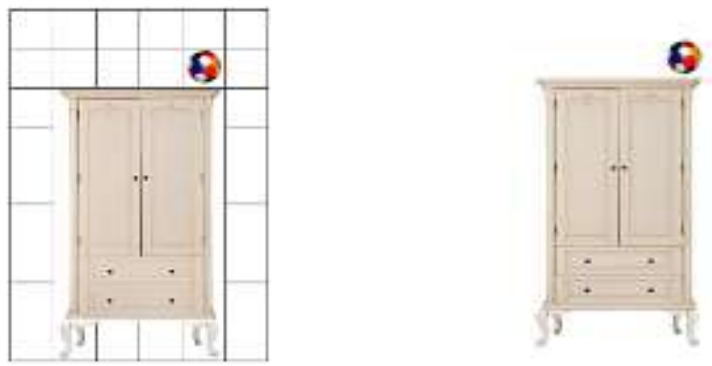

Katılımcılardan her sahneye bakmaları ve konumlanan ile konumlayan arasındaki ilişkiyi verilen tümcelerdeki boşlukları doldurarak betimlemeleri istenmiştir.

(9) “Top dolabin

Konumlanan ve konumlayan olan nesnelerin büyüklüklerine göre sorgulanan alan ile çerçevenin büyüklüğü de farklılık göstermektedir. Uygulamada toplam 142 farklı konumlanan-konumlayan ilişkisi sorgulanmıştır. 


\subsubsection{Görevlerde Konumlanan ve Konumlayan Olan Nesnelerin Seçilme Nedenleri}

Bir nesnenin işlevsel özelliklerinin uzamsal betimlemeleri etkileyebileceği çeşitli araştırmacılar tarafından iddia edilmiş ve gösterilmiştir (Herskovits, 1986; 1998; Vandeloise, 1986; 1994; Carlson-Radvansky \& Radvansky, 1996; Coventry, 1998; Coventry \& Prat-Sala, 1998). Örneğin, Carlson-Radvansky and Radvansky (1996) nesneler arasındaki işlevsel ilişkinin farklı uzamsal ilişkilerin kurulmasına neden olduğunu göstermiştir.

İşlevsel özelliklerin yanında uzamsal ilişkiyi etkileyen bir başka etken de nesnelerin içsel olarak bir yöne sahip olup olmadıklarıdır (Levelt, 1996; Levinson 1996, 2003).

$\mathrm{Bu}$ çerçevede bu çalışmada her görevde farklı özelliklerde olan nesneler konumlanan ve konumlayan olarak seçilmiştir.

Görev 1'de konumlanan olarak bir daire, konumlayan olarak da bir kare tercih edilmiştir. İlk görevde üç boyutlu iki nesne yerine iki geometrik şekil arasındaki uzamsal ilişki saptanmak istenmiştir. İki nesnenin de işlevsel ya da içsel herhangi bir özelliği yoktur, sadece uzamsal sahnede yer alan iki şekilden ibarettirler. Bu yüzden başlangıç görevi olarak kullanılmıştır.

Görev 2'de hareketli üç nesne durağan uzamsal sahnede kullanılmıştır. Bu görevde içsel yöne sahip hareketli nesneler arasındaki durağan uzamsal ilişki saptanmak istenmiştir. Konumlayan olan kayığın işlevsel, içsel ve uzamsal sahnedeki özellikleri şöyledir:

1. Kayık, hareket yönüne bağlı olarak içsel yöne sahiptir. Kayığın hareket yönü onun önüdür. Önüne bağl1 olarak da diğer yönleri belirlenir.

2. Kayık, yatay olarak geniş bir nesnedir. Yatay eksende dikey eksene göre daha geniş bir yer kaplar.

3. Uzamsal sahnede önü sağ tarafa bakar bir biçimde yan durmaktadır.

4. Uzamsal sahnede yan tarafları farklı açılardan ölçmek için elverişli bir nesnedir.

İlk 18 sahnede konumlanan olan kuş ile son 18 sahnede konumlanan olan balığın işlevsel, içsel ve uzamsal sahnedeki özellikleri şöyledir:

1. Hem kuş hem de balık kafa yönlerine doğru içsel olarak öne sahiptir. Hareket yönü olarak kayıkla aynı işlevsel özelliklere sahiptirler.

2. Hem kuş hem de balı hayvanbiçimli modele (the zoomorphic model: Clark, 1973) göre içsel yönlere sahiptir. Bu modele göre kafa $\rightarrow$ ön; kıç, kuyruk $\rightarrow$ arka; sırt $\rightarrow$ üst; karın $\rightarrow$ alt olarak adlandırılır.

3. Uzamsal sahnede her ikisinin de yönü sağ tarafa doğrudur ve görev boyunca değiştirilmemiştir. 
Görev 3'te konumlanan olarak bir top, konumlayan olarak da yan duran, sağ tarafa doğru bakan bir adam seçilmiştir. Bu görevde içsel yöne sahip bir konumlayan ile içsel yöne sahip olmayan bir konumlanan arasındaki uzamsal ilişki sorgulanmak istenmiştir. Konumlayan olan adamın içsel, işlevsel ve uzamsal sahnedeki özellikleri şöyledir:

1. Adam, insanbiçimli modele (the anthropomorphic model: Clark, 1973) göre içsel yönlere sahiptir. Bu modele göre yüz, göz, alın, ağız, göğüs $\rightarrow$ ön; sırt $\rightarrow$ arka; kafa $\rightarrow$ üst; kıç, kalça, ayak $\rightarrow$ alt; kulak, yanak, kaburgalar $\rightarrow$ yan olarak adlandırılmaktadır.

2. Uzamsal sahnede sağa doğru yan durmaktadır ve bu görev boyunca değiştirilmemiştir.

3. İnsan bedeni; uzamsal referans çerçevelerinin seçiminde de belirleyici rol oynamaktadir.

4. İnsan bedeni, konumlayanı parçalı olarak kullanmaya çok yatkındır.

Konumlanan olan top ise herhangi bir içsel yöne sahip değildir. Bir uzamsal ilişkide yönlerini konumlayandan ya da konuşucunun görüş açısından alır.

Görev 4'te konumlanan olarak tekrar bir top, konumlayan olarak ise ayaklı bir eşya dolabı tercih edilmiştir. Görev 3 'te olduğu gibi bu görevde de içsel yöne sahip bir konumlayan ile içsel yöne sahip olmayan bir konumlanan arasındaki uzamsal ilişki belirlenmek istenmiştir. Konumlayan olan dolabın içsel, işlevsel ve uzamsal sahnedeki özellikleri şöyledir:

1. İşlevsel özelliklerine bağlı olarak bir içsel yönü vardır. Kullanımsal olarak kapaklarının ve çekmecelerinin olduğu taraf, dolabın önüdür.

2. Dolap, hem dikey olarak uzun hem de yatay olarak geniş bir nesnedir. Hem dikey hem de yatay eksende geniş bir yer kaplamaktadır.

3. Uzamsal sahnede dolabın önü katılımcıya doğru durmaktadır.

4. İşlevsel özelliklerine göre konumlayan olarak parçalı kullanılabilir.

5. Dolabın ayaklı olması alt kısmının içsel olarak denetlenmesini sağlamaktadır.

Konumlanan olan top ise herhangi bir içsel yöne sahiptir. Bir uzamsal ilişkide yönlerini konumlayandan ya da konuşucunun görüş açısından alır.

\subsection{Uygulama Süreci}

Uygulama, sınıf ortamında katılımcıların birbirleriyle etkileşim halinde olmayacakları biçimde yaklaşık 10 - 15 kişiden oluşan gruplarla uygulanmıştır. Görevlerdeki görseller, gerçek boyutlarına uygun olması açısından projeksiyon 
cihazıyla duvara yansitılmış ve katılımcılardan ellerindeki kağı̆tlardaki tümceleri yazılı olarak tamamlamaları istenmiştir.

Uygulama iki bölüme ayrılmıştır. Birinci bölüm Görev 1 ve 2'den, ikinci bölüm de Görev 3 ve 4 'ten oluşmaktadır. Görseller arasındaki geçiş süresi otomatik olarak ayarlanmıştır. Temel uygulama öncesinde yapılan pilot uygulamada ilk iki görev toplam 32 katılımcıya uygulanmış olup katılımcılar görevleri bilgisayar karşısında bireysel olarak tamamlamışlardır. Pilot uygulamanın ortalama tamamlanma süresi 73 dakika ile 18 dakika arasında değişmektedir. Temel uygulamanın süresi, bu süreler göz önünde bulundurularak hesaplanmıştır. Her görsel arasındaki geçiş süresi 10 saniyedir ve her 10 görselde bir boş bir görsel görüntülenmektedir.

Birinci bölüm, toplam 76 görselden oluşmakta olup 16 dakika sürmektedir. Bu bölüm bittikten sonra katılımcılara dinlenmeleri için biraz zaman verilmiştir. Daha sonra ikinci bölüme geçilmiştir. İkinci bölüm ise toplam 66 görselden oluşmaktadır ve 13 dakika sürmektedir. Uygulamanın tamamlanma süresi dinlenme süresi hariç yaklaşık 30 dakikadır.

\subsection{Verilerin Çözümlenmesi}

Öncelikle kadın ve erkek katılımcıların dört görev için tercih ettikleri uzamsal terimler uzamsal şablonlara yerleştirilmiştir. Bütün katılımcıların her görev için oluşturduğu uzamsal şablonlar ayrı ayrı düzenlenmiştir. $\mathrm{Bu}$ düzenlemeler sonucunda her görev için 80 farklı uzamsal şablon ortaya çıarken uygulamanın tümü için toplam 320 farklı uzamsal şablon çalışmanın veritabanını oluşturmuştur.

Elde edilen veriler, çalışmada önce bir uzamsal sahneyi dilsel olarak ifade edebilmek için işe koşulan, zihinsel bir işlem olan uzamsal referans çerçevelerine göre çözümlenmiştir.

Her katılımcı için oluşturulan uzamsal şablonlar incelenerek tercih edilen uzamsal referans çerçeveleri saptanmıştır. Saptanan uzamsal referans çerçeveleri her görev için ayrı ayrı kadın ve erkek katılımcılar karşılaştırılarak çözümlenmiştir. Her görevde en sık tercih edilen uzamsal referans çerçeveleri tespit edilmiş̧ir.

Uygulamayı oluşturan dört görev için ayrı ayrı incelenen uzamsal referans çerçeveleri daha sonra uygulamanın bütünü açısından değerlendirilmiştir.

\subsection{Sinirlllıklar}

1. Çalışmanın amacı uzamsal referans çerçevelerin Türkçedeki görünümlerini betimlemek olduğu için farklı uzamsal kavramlaştırmalar inceleme konusu edilmemiştir. 
2. Uzaklık, yön, hareket, güç gibi etmenler çalışmanın sınırları dahilinde değildir.

3. Konumlanan ve konumlayanın belirli olarak verildiği sınırlı setten yapılan üretim görevleri olduğu için nesnelerin büyüklük-küçüklük gibi özellikleri bir değişken değildir.

4. Çalışma farklı meslek gruplarına yönelik bir dili çözümlememektedir, günlük dile özgü uzamsal çözümlemeler yapılmıştır.

\section{Bulgular}

Bir uzamsal sahneyi dilsel olarak ifade edebilmek için o sahneye uygulanan uzamsal referans çerçevelerinin seçimine birey özgül olarak karar vermektedir. Tversky'e (1991) göre bir uzamsal sahnede bir nesnenin konumunu ifade etmek için sadece bir tane uzamsal referans çerçevesi kullanılmayabilir. Uygun uzamsal referans çerçevesi bireyin deneyimine ya da durumsal bağlama göre seçilir. Taylor \& Tversky (1992) İngilizce ve Japonca gibi üç referans çerçevesinin de kullanıldığı dillerde insanların bazen aynı betimleme içinde bilinçsiz bir biçimde referans çerçevesi değiştirebildiğini belirtmektedir. Bunun yanında Levelt (1996) da referans çerçeve seçiminin birey tarafından konuşulan dile ve bireyin kültürel altyapısına bağlı olduğunu iddia etmektedir. Carlson-Radvansky \& Irwin (1994) uzamsal referans çerçevesi seçiminde bir başlangıç süreci olduğunu ve bu süreçte çerçevelerin aynı anda aktifleştiğini ve seçilmek için yarıştıklarını belirtmektedir. Carlson-Radvansky \& Radvansky (1996) ise konumlanan ile konumlayan arasındaki işlevsel ilişkinin referans çerçevesi seçimini etkilediğini iddia etmektedir. Uzamsal referans çerçeve seçimini etkileyen bu etkenler, uzamsal dile de yansımaktadır. Bu yüzden uzamsal ifadeleri yorumlarken belirli bir derecede anlam bulanıklığını varsaymak gerekir.

$\mathrm{Bu}$ başlık altında uygulamada yer alan dört görevde katılımcılar tarafindan tercih edilen referans çerçeveleri çeşitli açılardan değerlendirilecektir.

\subsection{Görev l'de Kullanılan Uzamsal Referans Çerçeveleri}

Konumlananın bir daire, konumlayanın ise bir kare olduğu ilk görevde her katılımcı toplam 40 farklı uzamsal sahneyi görüntülemiştir. Görev 1'e ilişkin uzamsal referans çerçeve grafiği aşağıdaki gibidir: 
Grafik 2. Görev 1'de kullanılan uzamsal referans çerçeveleri

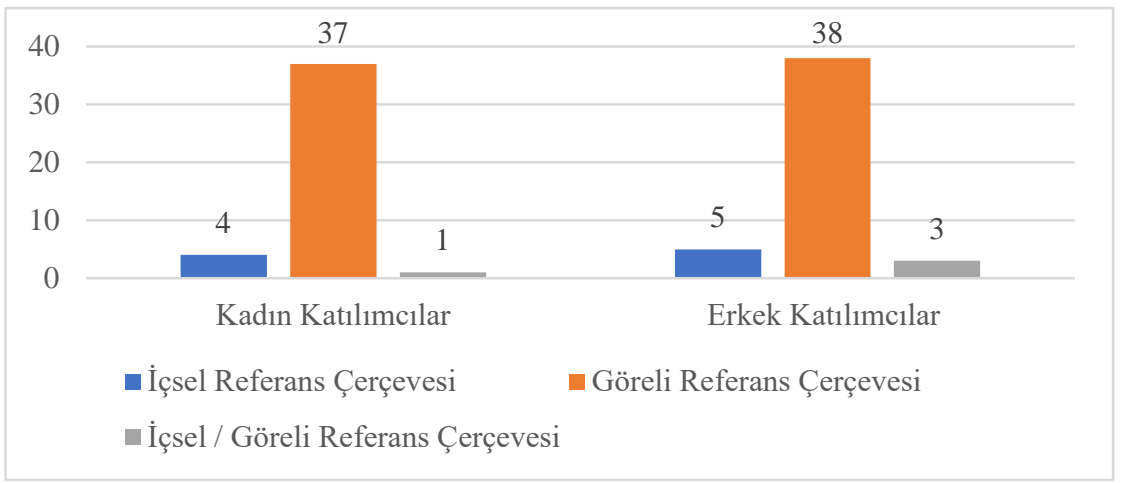

Görev 1'e katılan kadın katılımcılardan 37 kişi göreli referans çerçevesini tercih ederken, 4 kişi de içsel referans çerçevesini tercih etmiştir. 1 katılımcının kullandığı uzamsal terimler arasında iki referans çerçevesini ayırabilecek terimler olmadığından hem içsel hem de göreli uzamsal referans çerçevesi olarak kabul edilmiştir.

Görev 1'e katılan erkek katılımcılardan 38 kişi göreli referans çerçevesini tercih ederken, 5 katılımcı da içsel referans çerçevesini tercih etmiştir. Kadın katılımcılarda olduğu gibi erkek katılımcılarda da 3 katılımcının hem içsel hem de göreli uzamsal referans çerçevesine dahil olabilecek uzamsal terimler kullandığı saptanmıştır.

Şekil 5. KE4'e ait uzamsal şablon

\begin{tabular}{|c|c|c|c|c|c|c|}
\hline $\begin{array}{l}1 . \\
\text { Üstünde }\end{array}$ & $\begin{array}{l}2 . \\
\text { Üstünde }\end{array}$ & $\begin{array}{l}3 . \\
\text { Üstünde }\end{array}$ & $\begin{array}{l}4 . \\
\text { Üstünde }\end{array}$ & $\begin{array}{l}5 . \\
\text { Üstünde }\end{array}$ & $\begin{array}{l}6 . \\
\text { Üstünde }\end{array}$ & $\begin{array}{l}7 . \\
\text { Üstünde }\end{array}$ \\
\hline $\begin{array}{l}8 . \\
\text { Üstünde }\end{array}$ & $\begin{array}{l}9 . \\
\text { Üstünde }\end{array}$ & $\begin{array}{l}10 . \\
\text { Üstünde }\end{array}$ & $\begin{array}{l}11 . \\
\text { Üstünde }\end{array}$ & $\begin{array}{l}12 . \\
\text { Üstünde }\end{array}$ & $\begin{array}{l}13 . \\
\text { Üstünde }\end{array}$ & $\begin{array}{l}14 . \\
\text { Üstünde }\end{array}$ \\
\hline $\begin{array}{l}15 . \\
\text { Yanında }\end{array}$ & $\begin{array}{l}16 . \\
\text { Yanında }\end{array}$ & & & & $\begin{array}{l}17 . \\
\text { Yanında }\end{array}$ & $\begin{array}{l}18 . \\
\text { Yanında }\end{array}$ \\
\hline $\begin{array}{l}19 . \\
\text { Yanında }\end{array}$ & $\begin{array}{l}20 . \\
\text { Yanında }\end{array}$ & & & & $\begin{array}{l}21 . \\
\text { Yanında }\end{array}$ & $\begin{array}{l}22 . \\
\text { Yanında }\end{array}$ \\
\hline $\begin{array}{l}23 . \\
\text { Yanında }\end{array}$ & $\begin{array}{l}24 . \\
\text { Yanında }\end{array}$ & & & & $\begin{array}{l}25 . \\
\text { Yanında }\end{array}$ & $\begin{array}{l}26 . \\
\text { Yanında }\end{array}$ \\
\hline $\begin{array}{l}27 . \\
\text { Altında }\end{array}$ & $\begin{array}{l}28 . \\
\text { Altında }\end{array}$ & $\begin{array}{l}29 . \\
\text { Altında }\end{array}$ & $\begin{array}{l}30 . \\
\text { Altında }\end{array}$ & $\begin{array}{l}31 . \\
\text { Altında }\end{array}$ & $\begin{array}{l}32 . \\
\text { Altında }\end{array}$ & $\begin{array}{l}33 . \\
\text { Altında }\end{array}$ \\
\hline $\begin{array}{l}34 . \\
\text { Altında }\end{array}$ & $\begin{array}{l}35 . \\
\text { Altında }\end{array}$ & $\begin{array}{l}36 . \\
\text { Altında }\end{array}$ & $\begin{array}{l}37 . \\
\text { Altında }\end{array}$ & $\begin{array}{l}38 . \\
\text { Altında }\end{array}$ & $\begin{array}{l}39 . \\
\text { Altında }\end{array}$ & $\begin{array}{l}40 . \\
\text { Altında }\end{array}$ \\
\hline
\end{tabular}


KE4 kodlu katılımcının Görev 1'e ait uzamsal şablonu incelendiğinde kullandığ uzamsal terimlerin hem içsel hem de göreli referans çerçevesine dahil olabileceği görülecektir. Bu katılımcı gibi kullandığı uzamsal terimlerin temelinde yer alan uzamsal referans çerçevesi net olarak belirlenemeyen katılımcılar her iki gruba da eklenmiştir.

Görev 1'in bulguları uzamsal referans çerçeveleri açısından değerlendirildiğinde kadın ve erkek katılımcılar arasında anlamlı bir fark bulunamamıştır. Toplam 80 katılımcıdan 75'i görüş açısını da uzamsal sahneye ekleyerek görüş açısı, konumlanan ile konumlayandan oluşan ve üçlü bir uzamsal ilişki gerektiren göreli referans çerçevesini tercih etmiştir.

Görev 1'de hem konumlanan olan daire hem de konumlayan olan kare içsel olarak bir yöne sahip değildir. Yani her iki nesnenin de kendine ait, belirgin bir altı-üstü, önü-arkası ya da sağı-solu yoktur. Görev 1'den elde edilen bulgular Imai vd. (1999) ile Sogo vd.'nin (2000) bulgularıyla örtüşmektedir. Eğer konumlanan ve konumlayanın içsel yönleri yoksa göreli referans çerçevesi tercih edilmektedir. Miller \& Johnson-Laird (1976), Vandeloise (1986) ve Borillo (1998) hem konumlananın hem de konumlayanın içsel yönleri olmadığında önün bağlamsal olarak konumlayana verildiğini ya da konuşucu tarafindan ona yansıtıldığını ve buradan hareketle konumlananın konumlandırıldığını belirtmektedirler.

\subsection{Görev 2'de Kullanılan Uzamsal Referans Çerçeveleri}

Konumlananın uçan bir kuş ya da yüzen bir balık, konumlayanın ise kayık olduğu ikinci görevde her katılımcı 36 farklı uzamsal sahneyi görüntülemiştir. Görev 2'ye ilişkin uzamsal referans çerçeve grafiği aşağıdaki gibidir:

Grafik 3. Görev 2'de kullanılan uzamsal referans çerçeveleri

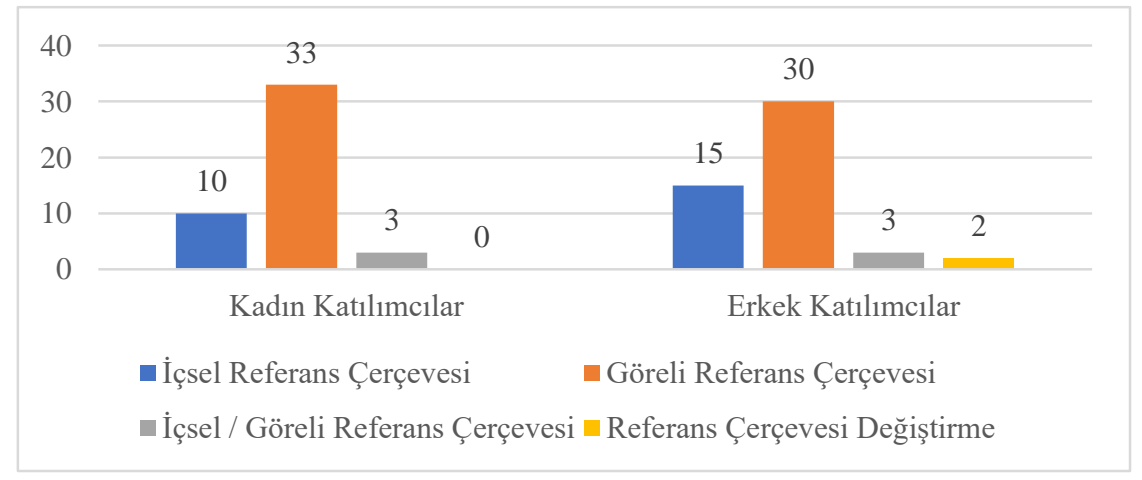


Görev 2'ye katılan kadın katılımcılardan 33'ü göreli referans çerçevesini tercih ederken 10'u da içsel referans çerçevesini tercih etmiştir. Yine bu katılımcılardan 3 'ünün kullandığı uzamsal terimler hem içsel hem de göreli referans çerçevesi başlığı altında değerlendirilebilmektedir.

Görev 2'ye katılan erkek katılımcılardan 30'u göreli referans çerçevesini tercih etmiş, 15 ' $\mathrm{i}$ ise içsel referans çerçevesini kullanmıştır. Bu katılımcılardan 3'ünün kullandığı uzamsal terimler hem içsel hem de göreli referans çerçevesi olarak kabul edilebilmektedir. Bunun yanında bu katılımcılar arasından 2 kişi de aynı görev içinde bir uzamsal referans çerçevesi ile başlamış, daha sonra farklı bir uzamsal referans çerçevesine geçiş yapmıştır. KE1 kodlu katılımcı ilk 20 sahnede göreli referans çerçevesini kullanırken 21 ile 36 arasındaki sahnelerde içsel referans çerçevesine geçiş yapmıştır. KE31 kodlu katılımcı ise ilk 29 sahnede göreli referans çerçevesini tercih ederken 30 ile 36 arasındaki sahnelerde içsel referans çerçevesine geçiş yapmıştır. KE1 kodlu katılımoının uzamsal referans çerçevesini değiştirdiği açıkken KE31 kodlu katılımcının son sahnelerde yaptığı değişiklik dikkat dağınıklığı ya da kafa karışıklığı sonucunda yapılmış olarak da yorumlanabilir.

Şekil 6'da görüleceği gibi KE1 kodlu katılımcı başta kendi görüş açısını temel alarak üçlü bir uzamsal ilişki kurmuş ve göreli referans çerçevesini tercih etmiştir. Ama görsel 21 ile birlikte kendi görüş açısını bir kenara bırakmış, kayığın içsel yönlerini kullanarak ikili uzamsal ilişki temelli içsel referans çerçevesine geçiş yapmıştır. Kayığın içsel yönlerini belirleyen onun hareket yönüdür. Kayığın hareket yönü onun ön kısmını göstermektedir ve bundan dolayı ön, kayık için güçlü bir içsel yöndür. KE1 kodlu katılımcıyı etkileyen ve uzamsal referans çerçevesini değiştirmesine neden olan etmenin bu özellik olduğu düşünülebilir. 
Sekil 6. KE1'e ait uzamsal sablon

\begin{tabular}{|c|c|c|c|c|c|c|}
\hline $\begin{array}{l}\text { 1.Sol üst } \\
\text { çaprazında }\end{array}$ & $\begin{array}{l}\text { 2. Sol üst } \\
\text { çaprazının } \\
\text { sağında }\end{array}$ & $\begin{array}{l}\text { 3. Sol üst } \\
\text { çaprazın } \\
\text { biraz } \\
\text { sağında }\end{array}$ & 4. Üzerinde & $\begin{array}{l}\text { 5. Sağ üst } \\
\text { çaprazın } \\
\text { biraz } \\
\text { solunda }\end{array}$ & $\begin{array}{l}\text { 6. Sağ üst } \\
\text { çaprazında }\end{array}$ & $\begin{array}{l}\text { 7. Sağ üst } \\
\text { çaprazın } \\
\text { sağında }\end{array}$ \\
\hline $\begin{array}{l}\text { 8. Sol üst } \\
\text { çaprazın } \\
\text { biraz } \\
\text { altında }\end{array}$ & $\begin{array}{l}\text { 9. Sol üst } \\
\text { çaprazın } \\
\text { biraz } \\
\text { yanında }\end{array}$ & 10. Sol üst & $\begin{array}{l}11 . \\
\text { Üzerinde }\end{array}$ & $\begin{array}{l}\text { 12. Sağ } \\
\text { üst }\end{array}$ & $\begin{array}{l}\text { 13. Sağ } \\
\text { üst }\end{array}$ & $\begin{array}{l}\text { 14. Sağ } \\
\text { çaprazında }\end{array}$ \\
\hline $\begin{array}{l}\text { 15. Sol } \\
\text { yanında }\end{array}$ & $\begin{array}{l}\text { 16. Sol } \\
\text { bitişiğinde }\end{array}$ & & & & $\begin{array}{l}\text { 17. Sağ } \\
\text { bitişiğinde }\end{array}$ & $\begin{array}{l}\text { 18. Sağ } \\
\text { yanında }\end{array}$ \\
\hline $\begin{array}{l}19 . \\
\text { Solunda }\end{array}$ & $\begin{array}{l}20 . \\
\text { Solunda }\end{array}$ & & & & $\begin{array}{l}21 . \\
\text { Solunda }\end{array}$ & $\begin{array}{l}22 . \\
\text { Solunda }\end{array}$ \\
\hline $\begin{array}{l}23 . \\
\text { Sağında }\end{array}$ & $\begin{array}{l}\text { 24. Sağ } \\
\text { altında }\end{array}$ & $\begin{array}{l}\text { 25. Sağ ön } \\
\text { ucun } \\
\text { yanında }\end{array}$ & $\begin{array}{l}\text { 26. Sağ ön } \\
\text { uçta }\end{array}$ & $\begin{array}{l}\text { 27. Sağ ön } \\
\text { uçta }\end{array}$ & $\begin{array}{l}28 . \\
\text { Önünde }\end{array}$ & $\begin{array}{l}29 . \\
\text { Önünde }\end{array}$ \\
\hline $\begin{array}{l}30 . \\
\text { Sağında }\end{array}$ & $\begin{array}{l}\text { 31. Sağ } \\
\text { çaprazında }\end{array}$ & $\begin{array}{l}\text { 32. Sağ } \\
\text { çaprazında }\end{array}$ & $\begin{array}{l}\text { 33. Sağ } \\
\text { çaprazında }\end{array}$ & $\begin{array}{l}\text { 34. Sağ ön } \\
\text { çaprazında }\end{array}$ & $\begin{array}{l}35 . \\
\text { Önünde }\end{array}$ & $\begin{array}{l}36 . \\
\text { Önünde }\end{array}$ \\
\hline
\end{tabular}

Görev 2'nin bulguları uzamsal referans çerçeveleri açısından değerlendirildiğinde toplam 80 katılımcıdan 63'ünün göreli referans çerçevesini tercih ettiği görülmektedir. Bu sayının içinde seçtiği uzamsal referans çerçeveleri net bir biçimde ayırt edilemeyen ya da aynı görev içinde referans çerçevesi değiştiren katılımcılar da bulunmaktadır.

Görev 2'de Görev 1'den farklı olarak hem konumlanan olan kuş ve balık hem de konumlayan olan kayık içsel yöne sahiptir. Yani her üç nesnenin kendine ait önü-arkası, altı-üstü ve bunlara bağlı olarak sağı-solu vardır. Buna rağmen katılımcıların büyük çoğunluğu göreli referans çerçevesini tercih etmiştir. Görev 2 sonucunda uzamsal referans çerçeve seçimine ilişkin elde edilen bulgular; Sogo vd.'nin (2000) bulguları ile örtüşmektedir. Bir uzamsal sahnede hem konumlanan hem de konumlayan içsel yöne sahipse göreli referans çerçevesi seçilmektedir. Bu bulgular, Miller \& Johnson-Laird (1976) ve Cox'un (1985) bulgularıyla ise örtüşmemektedir. Onların iddiasına göre konumlayanın içsel bir önü varsa büyük çoğunlukla içsel referans çerçevesi tercih edilmektedir. Bu bulgular aynı zamanda Levelt'ın (1984) iddiasıyla da uyuşmamaktadır. Levelt'a (1984) göre konumlanan içsel bir öne sahip olduğunda ya da hareket ettiğinde ve önünde/arkasında ilgeçleri kullanıldığında içsel referans çerçevesi baskındır. 
Imai vd.'ye (1999) göre referans çerçeve seçimini etkileyen etkenlerden biri de konumlayanın görüntüleyiciye göre yönelimidir. Konumlayan görüntüleyiciye yanlamasına duruyorsa hem içsel hem de göreli referans çerçevesi tercih edilebilmektedir. Özellikle sağ ve sol kullanımlarında baskın olarak göreli referans çerçevesi devreye girmektedir.

Burada diğer bir önemli nokta ise nesne türüdür. Nesnenin içsel önünün gücü ve insanların nesneyle etkileşimi referans çerçevesi seçimini büyük ölçüde etkilemektedir. Herskovits'e (1986) göre konumlayanın (örneğin; araba vb.) hem içeriden hem de dışarıdan görülebileceği durumlarda sağ ve sol tarafların belirlenmesinde çatışma olmaktadır. Görev 2'de konumlayan olan kayık için de içine binildiğinde farklı dışarıdan bakıldığında farklı sağ ve sol tarafları belirlenebilir. Böyle bir durumda konuşucu anlam karmaşasını önlemek için kendi görüş açısına göre konumlanış ilişkisi kurmaktadır.

\subsection{Görev 3 'te Kullanılan Uzamsal Referans Çerçeveleri}

Konumlananın bir top ve konumlayanın ayakta yan duran bir adam olduğu üçüncü görevde her katılımcı toplam 36 uzamsal sahne görüntülemiştir. Görev 3'e ilişkin uzamsal referans çerçeve grafiği aşağıdaki gibidir:

Grafik 4. Görev 3'de kullanılan uzamsal referans çerçeveleri

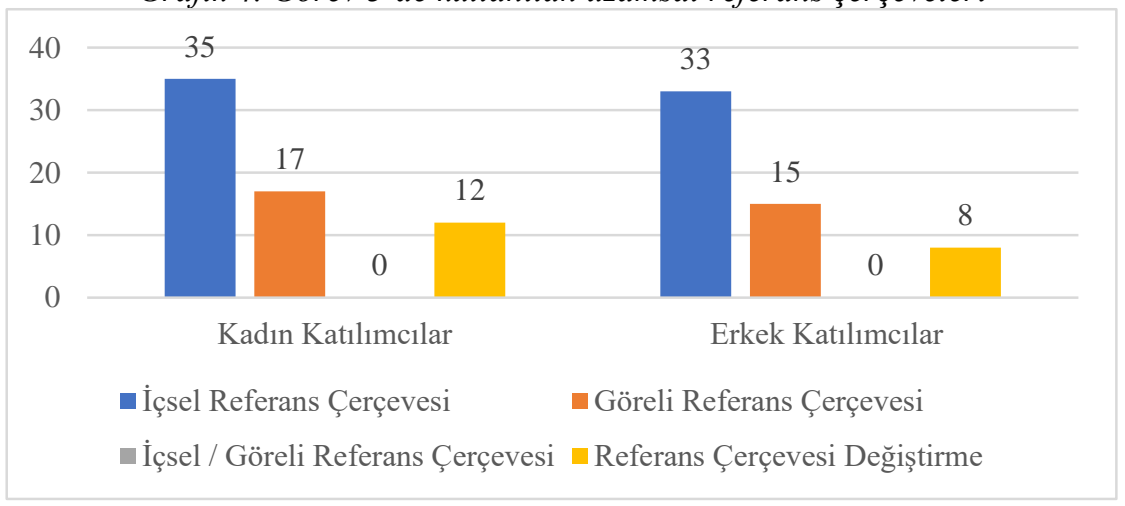

Görev 3'e katılan 40 kadın katılımcıdan 35'i içsel referans çerçevesini tercih ederken 17 kişi göreli referans çerçevesini tercih etmiş̧ir. Bu iki grup içinde yer alan 12 katılımcı da göreve başlarken kullandığı uzamsal referans çerçevesini görev içinde değiştirmiştir. KK2, KK3, KK9, KK10, KK23, KK28, KK31, KK34, KK36 kodlu katılımcılar görevin ilk 12 sahnesinde göreli referans çerçevesi kullanırken 13 ile 36 arasındaki uzamsal sahnelerde içsel referans çerçevesine geçiş yapmışlardır. Aynı durumda KK7 ilk 16, KK33 ilk 13, KK35 
ilk 4 sahnede göreli referans çerçevesi ile başlayıp sonrasında içsel referans çerçevesini tercih etmişlerdir.

Görev 3'e katılan 40 erkek katılımcıdan 33'ü içsel referans çerçevesini seçerken 15'i de göreli referans çerçevesini seçmiştir. Bu iki grubun içinde yer alan 8 katılımcı da göreve göreli referans çerçevesiyle başlayıp daha sonra içsel referans çerçevesine geçiş yapmışladır. KE16, KE17, KE31, KE37 kodlu katılımcılar ilk 12, KE7 ile KE34 ilk 13, KE18 ilk 16 ve son olarak KE19 ilk 8 sahnede göreli referans çerçevesini tercih edip bu sahnelerden sonrakilerde içsel referans çerçevesini kullanmışlardır.

Şekil 7. KK10'a ait uzamsal şablon

\begin{tabular}{|c|c|c|c|c|c|}
\hline $\begin{array}{l}\text { 1. Sol üst } \\
\text { çaprazında }\end{array}$ & $\begin{array}{l}\text { 2. Sol üst } \\
\text { yakınında }\end{array}$ & $\begin{array}{l}3 . \\
\text { Üstünde }\end{array}$ & $\begin{array}{l}\text { 4. Sağ üst } \\
\text { yakınında }\end{array}$ & $\begin{array}{l}\text { 5. Sağ üst } \\
\text { çaprazında }\end{array}$ & $\begin{array}{l}\text { 6. Sağ üst } \\
\text { çaprazında }\end{array}$ \\
\hline $\begin{array}{l}\text { 7. Sol üst } \\
\text { yakınında }\end{array}$ & $\begin{array}{l}\text { 8. Sol üst } \\
\text { yakınında }\end{array}$ & $\begin{array}{l}9 . \\
\text { Üstünde }\end{array}$ & $\begin{array}{l}\text { 10. Sağ } \\
\text { üstünde }\end{array}$ & $\begin{array}{l}\text { 11. Sağ üstü } \\
\text { yakınında }\end{array}$ & $\begin{array}{l}\text { 12. Sağ üst } \\
\text { yakınında }\end{array}$ \\
\hline $\begin{array}{l}13 . \\
\text { Arkasında } \\
\text { yakınında }\end{array}$ & $\begin{array}{l}14 . \\
\text { Arkasında } \\
\text { bitişiğinde }\end{array}$ & & & $\begin{array}{l}\text { 15. Önünde } \\
\text { bitişiğinde }\end{array}$ & $\begin{array}{l}\text { 16. Önünde } \\
\text { uzağında }\end{array}$ \\
\hline $\begin{array}{l}17 . \\
\text { Arkasında }\end{array}$ & $\begin{array}{l}18 . \\
\text { Arkasında } \\
\text { yakınında }\end{array}$ & & & $\begin{array}{l}\text { 19. Önünde } \\
\text { yakınında }\end{array}$ & $\begin{array}{l}\text { 20. Önünde } \\
\text { uzağında }\end{array}$ \\
\hline $\begin{array}{l}21 . \\
\text { Arkasinda }\end{array}$ & $\begin{array}{l}22 . \\
\text { Arkasında } \\
\text { yakınında }\end{array}$ & & & $\begin{array}{l}\text { 23. Önünde } \\
\text { yakınında }\end{array}$ & 24. Önünde \\
\hline $\begin{array}{l}25 . \\
\text { Arkasında } \\
\text { altında }\end{array}$ & $\begin{array}{l}26 . \\
\text { Arkasında } \\
\text { altında } \\
\end{array}$ & & & $\begin{array}{l}\text { 27. Önünde } \\
\text { biraz altında }\end{array}$ & $\begin{array}{l}\text { 28. Önünde } \\
\text { uzağında }\end{array}$ \\
\hline $\begin{array}{l}29 . \\
\text { Arkasında } \\
\text { uzağında }\end{array}$ & $\begin{array}{l}30 . \\
\text { Arkasında } \\
\text { alt yakınında }\end{array}$ & & & $\begin{array}{l}\text { 31. Önünde } \\
\text { alt } \\
\text { yakınında }\end{array}$ & $\begin{array}{l}\text { 32. Önünde } \\
\text { alt uzağında }\end{array}$ \\
\hline $\begin{array}{l}33 . \\
\text { Ayağının } \\
\text { arkasında }\end{array}$ & $\begin{array}{l}34 . \\
\text { Ayağının } \\
\text { arkasında }\end{array}$ & & & $\begin{array}{l}35 . \\
\text { Ayağının } \\
\text { önünde }\end{array}$ & $\begin{array}{l}36 . \\
\text { Ayağının } \\
\text { önünde }\end{array}$ \\
\hline
\end{tabular}

Şekil 7'de görüldüğü gibi KK10 kodlu katılımcı ilk 12 sahnede kendi görüş açısına göre konumlanan ile konumlayanı konumlandırmış ve göreli referans çerçevesi kullanmıştır. 13. sahneyle birlikte konumlanan, konumlayanın eksenlerine tam olarak girdiğinde ise içsel referans çerçevesine geçiş yapmıştır. İnsan vücudunun içsel yönlerinin güçlü olmasının, referans çerçeve değişimini etkilediği görülmektedir. 
Görev 3'ün bulguları uzamsal referans çerçeveleri bağlamında değerlendirildiğinde toplam 80 katılımcıdan 68'i içsel referans çerçevesini tercih ettiği bulgulanmaktadır. Bu 68 katılımcı içinde görev içinde uzamsal referans çerçevesi değiştiren 20 katılımı da yer almaktadır. Bunun yanında kadın ve erkek katılımcılar arasında uzamsal referans çerçevesi kullanımı açısından anlamlı bir fark bulunamamıştır.

Diğer iki görevden farklı olarak Görev 3'te ağırlıklı olarak içsel referans çerçevesi tercih edilmiştir. Bunun öncelikli nedeni, konumlayan olan insan vücudunun güçlü içsel yönlere sahip olmasıdır. Bunun yanında konumlanan olan topun içsel bir yönünün olmaması da içsel referans çerçevesi seçimini tetiklemektedir. Görev 3'ün sonucunda uzamsal referans çerçevesi seçimine ilişkin bulgular; Imai vd. (1999) ile Sogo vd.'nin (2000) bulgularını desteklemektedir. Bir uzamsal sahnede konumlayan olan nesnenin içsel yönleri varsa, bunun yanında konumlanan olan nesnenin ise içsel yönleri yoksa içsel referans çerçevesi baskın olarak tercih edilmektedir. Bu bulgular, konumlayanın içsel bir önü olduğunda büyük çoğunlukla içsel referans çerçevesi tercih edildiğini iddia eden Miller \& Johnson-Laird (1976), Cox (1985) ve Levelt'ın (1984) bulgularıyla da örtüşmektedir.

Ama bu eğilim, daha önce Görev 2'de görüldüğü gibi konumlayanın içsel yönlerinin gücüne göre farklılık gösterebilmektedir. Imai vd.'ye (1999) göre insan, hayvan ya da insan biçimli nesneler (oyuncak bebek, robot vb.) televizyon, sandalye gibi diğer içsel öne sahip olan nesnelerden daha güçlü içsel yönlere sahiptir. Konumlayanın insan olması Görev 3'te içsel referans çerçevesinin baskın olarak kullanılmasına neden olmuştur.

\subsection{Görev 4'te Kullanılan Uzamsal Referans Çerçeveleri}

Konumlananın bir top, konumlayanın ise ayaklı bir giysi dolabı olduğu dördüncü görevde her katılımcı toplam 30 farklı uzamsal sahne görüntülemiştir. Görev 4'e ilişkin uzamsal referans çerçeve grafiği aşağıdaki gibidir: 
Grafik 5. Görev 4'te kullanılan uzamsal referans çerçeveleri

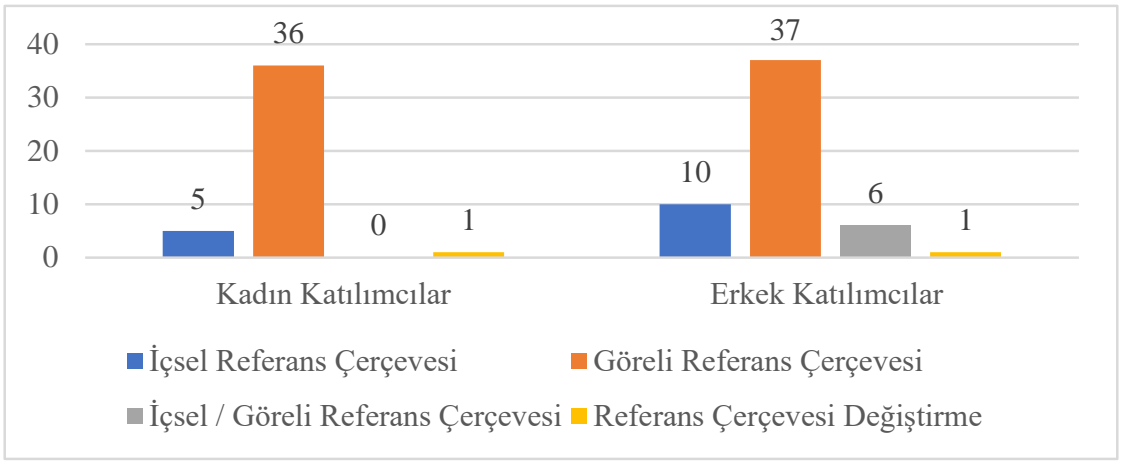

Görev 4'e katılan 40 kadın katılımcıdan 36'sı göreli referans çerçevesini tercih ederken 5'i de içsel referans çerçevesini tercih etmiştir. KK39 kodlu katılımcı ilk 6 sahnede içsel referans çerçevesini seçmiş, ama 7 ile 30 arasındaki sahnelerde göreli referans çerçevesiyle devam etmiştir.

Görev 4'e katılan erkek katılımcılardan 37'si göreli referans çerçevesini, 10'u da içsel referans çerçevesini kullanmıştır. Bu katılımcılar arasından 6'sının kullandığı uzamsal terimler hem içsel hem de göreli referans çerçevesini işaret ettiği için her iki grupta da yer almışlardır. KE24 kodlu katılımcı ilk 16 sahnede içsel referans çerçevesini tercih ederken sonrasında göreli referans çerçevesine geçiş yapmıştır. 
Şekil 8. KE24'e ait uzamsal şablon

\begin{tabular}{|c|c|c|c|c|c|}
\hline 1. Üstünde & 2. Üstünde & 3. Üstünde & 4. Üstünde & 5. Üstünde & 6. Üstünde \\
\hline 7. Üstünde & 8. Üstünde & 9. Üstünde & 10. Üstünde & 11. Üstünde & 12. Solunda \\
\hline 13. Sağında & & & & & 14. Solunda \\
\hline 15. Sağında & & & & & 16. Solunda \\
\hline 17. Solunda & & & - & & 18. Sağında \\
\hline 19. Solunda & & & & & 20. Sağında \\
\hline 21. Solunda & & & & & 22. Sağında \\
\hline 23. Solunda & & - & - & & 24. Sağında \\
\hline 25. Solunda & 26. Altında & 27. Altında & 28. Altında & 29. Altında & 30. Sağında \\
\hline
\end{tabular}

Şekil 8'de görüldüğü gibi KE24 ilk 16 uzamsal sahnede konumlayan olan giysi dolabının içsel yönlerini kullanarak konumlanan olan topu konumlandırırken 17'den itibaren kendi görüş açısını da işin içine katarak göreli referans çerçevesini kullanmaya başlamıştır.

Görev 3'te uzamsal referans çerçeve değișimi; göreli referans çerçevesinden içsel referans çerçevesine doğru olurken Görev 4'te tam tersi bir durum söz konusudur. Uzamsal referans çerçevesi değiştiren her iki katılımcı da göreve içsel referans çerçevesi kullanarak başlamış, sonrasında göreli referans çerçevesine geçiş yapmıştır.

Görev 4'ün geneline bakıldığında toplam 80 katılımcıdan 73'ü göreli referans çerçevesini tercih etmiştir. Diğer üç görevde olduğu gibi kadın ve erkek katılımcılar arasında uzamsal referans seçimi konusunda anlamlı bir fark bulunamamıştır.

Görev 3'te olduğu gibi Görev 4'te de konumlayan olan nesne içsel yönlere sahipken konumlanan olan nesnenin içsel yönleri yoktur. Ama Görev 3'ün aksine göreli referans çerçevesi baskın olarak tercih edilmiştir. Bu da konumlayan olan nesnenin içsel yönlerinin güçlü olmadığını göstermektedir. İnsan vücudu içsel yönleri açısından güçlü bir konumlayanken, giysi dolabı içsel yönleri açısından 
zayıf bir konumlayandır. İnsan, hayvan ya da insan biçimli nesnelerin (oyuncak bebek, robot vb.) televizyon, sandalye gibi diğer içsel öne sahip olan nesnelerden daha güçlü içsel yönlere sahip olduğu iddiasını öne süren Imai vd.'ye (1999) göre insanların yüz yüze etkileşim içinde kullandığı televizyon gibi nesnelerle özellikle göreli referans çerçevesi tercih edilmektedir. Görev 4 'te konumlayan olan giysi dolabı da televizyon gibi insanların yüz yüze etkileşim içinde kullandığı bir nesnedir ve elde edilen bulgular Imai vd.'nin (1999) bulgularını desteklemektedir.

Bunun yanında Sogo vd.'nin (2000) iddiası da yine bu çalışmada Türkçeden elde edilen veri ile desteklenmektedir. Konumlayan olan nesne içsel yönlere sahip olmasına karşın konuşucular göreli referans çerçevesini tercih ediyorsa bu onların yorumlamada anlam bulanıklığına neden olmak istemediklerini göstermektedir.

Görev 4'ten elde edilen bulgular, konumlayanın kayık olduğu Görev 2'de olduğu gibi konumlayanın içsel bir önü olduğunda büyük çoğunlukla içsel referans çerçevesi tercih edildiğini iddia eden Miller \& Johnson-Laird (1976), Cox (1985) ve Levelt'1n (1984) bulgularını desteklememektedir.

\subsection{Uzamsal Referans Çerçevelerinin Uygulamanın Bütünü Açısından Değerlendirilmesi}

Uygulamanın bütününde kullanılan uzamsal referans çerçeveleri grafiği aşağıdaki gibidir:

Grafik 6. Uygulamanın bütünü açısından uzamsal referans çerçeveleri

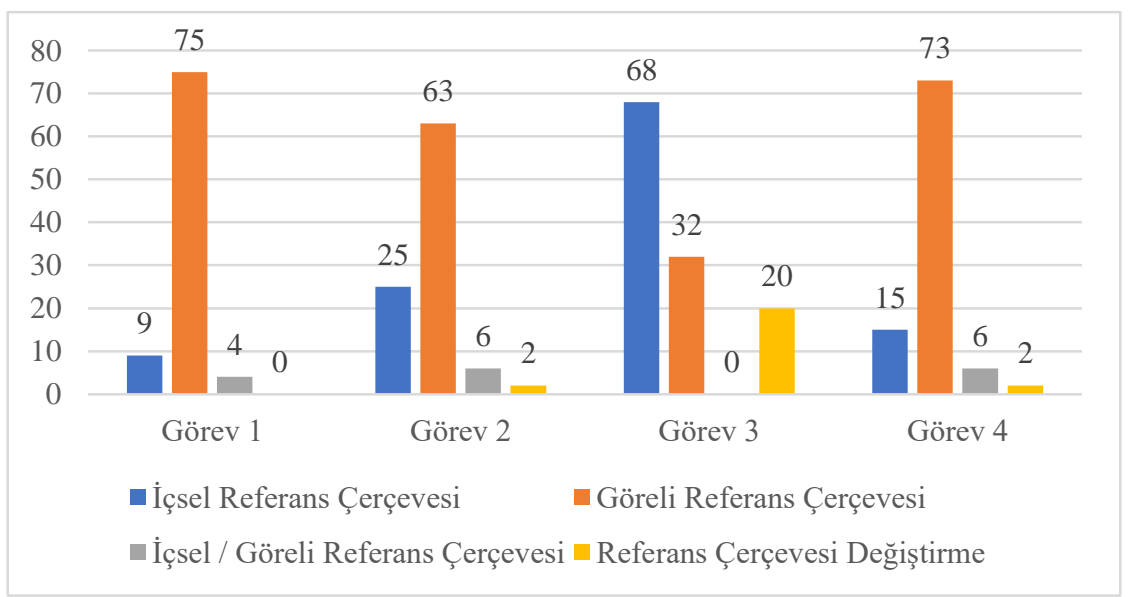


Uzamsal referans çerçeveleri, uygulamanın bütünü açısından değerlendirildiğinde katılımcıların Görev 1, 2 ve 4'te baskın olarak göreli referans çerçevesini; Görev 3 'te ise baskın olarak içsel referans çerçevesini tercih ettikleri görülmektedir.

Genel tablo incelendiğinde katılımcıların bütün görevlerde tek bir uzamsal referans çerçevesi kullanma eğiliminde olmadıkları, uygun koşullarda farklı uzamsal referans çerçeveleri kullandıkları saptanmıștır.

Cinsiyet değişkeni açısından incelendiğinde genel görünüm Grafik 7'deki gibidir:

Grafik 7. Cinsiyet değişkeni açısından uzamsal referans çerçeveleri

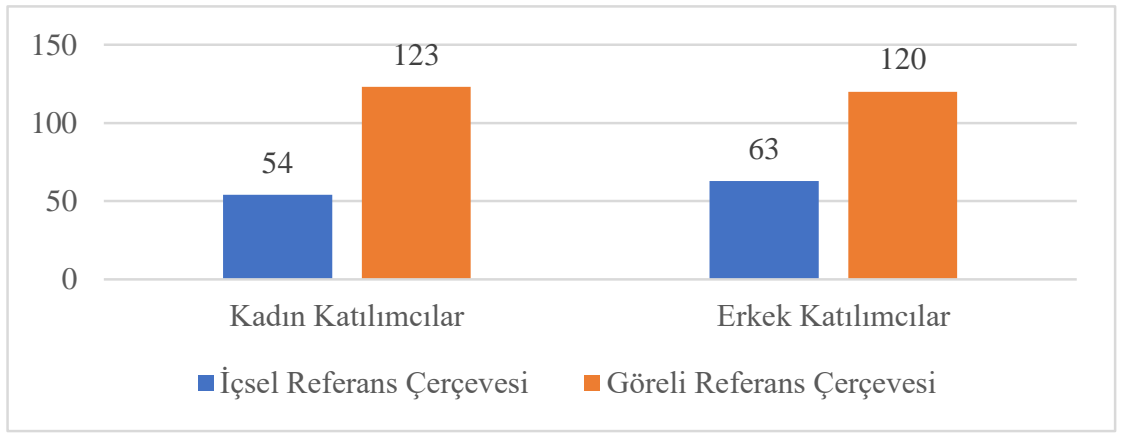

Uzamsal referans çerçevesi seçimi genel görünümü açısından incelendiğinde kadın katılımcılar toplamda $123 \mathrm{kez}$ göreli, 54 kez içsel referans çerçevesi kullanırken erkek katılımcılar 120 kez göreli, 63 kez içsel referans çerçevesi kullanmıştır. Elde edilen bu bulgular, uzamsal yetenek konusunda cinsiyet fark1 olduğunu; erkeklerin uzamsal görüntüleme, uzamsal alg1 ve zihinsel rotasyon olmak üzere üç temel görevde daha yüksek performans gösterdiğini, kadınların ise nesne konumlandırma hafızası ile nesnelerin ve şekillerin görsel tanınmasında daha iyi olduklarını iddia eden Linn \& Petersen (1985) ve Weiss vd.'nin (2003) bulgularını desteklememektedir. Alanyazındaki bu bulgular 1şığında kadın katılımcıların nesne-merkezli olan içsel referans çerçevesini daha fazla tercih etmeleri öngörülmüştür ama bununla ilgili herhangi bir bulguya erişilememiştir.

Uzamsal referans çerçeveleri fen bilimleri ve sosyal bilimler açısından değerlendirildiğinde genel görünümler Grafik 8 ve 9'daki gibidir: 
Grafik 8. Fen bilimleri açısından uzamsal referans çerçeveleri

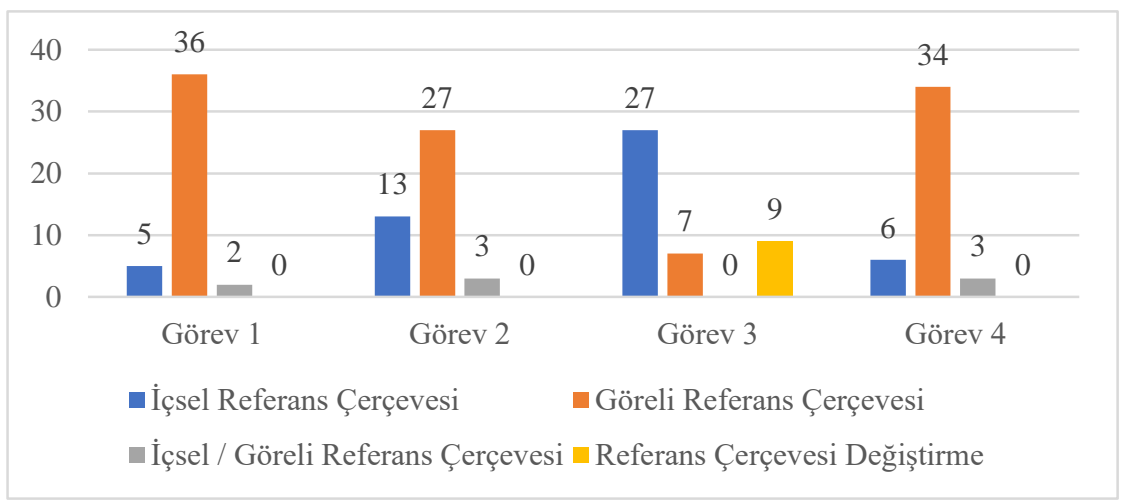

Grafik 9. Sosyal bilimler açısından uzamsal referans çerçeveleri

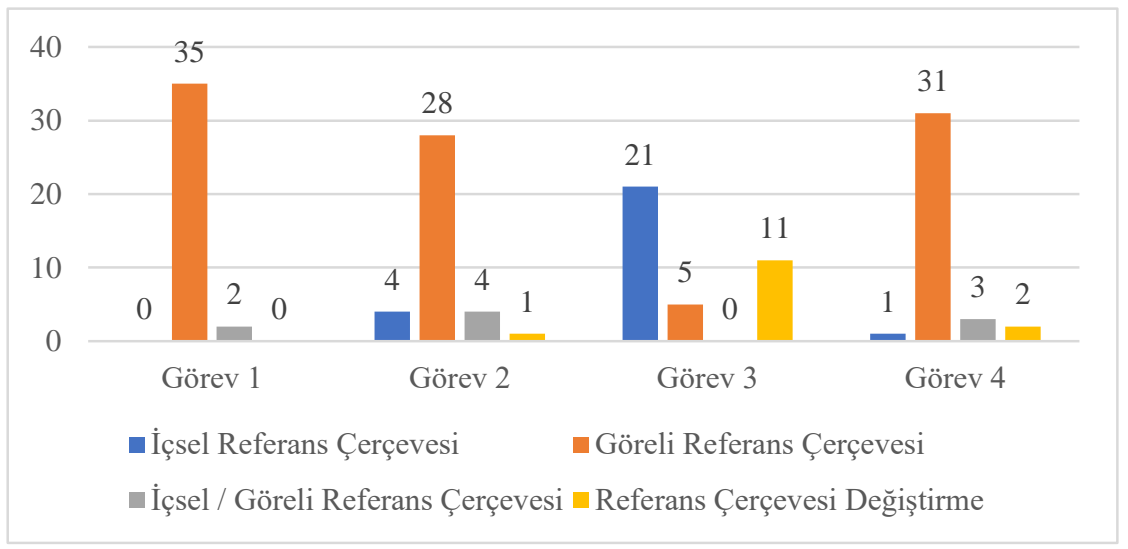

Fen bilimlerinden gelen katılımcılar uygulama bütününde 112 kez göreli referans çerçevesi kullanırken sosyal bilimlerden gelen katılımcılar 108 kez göreli referans çerçevesi kullanmıştır. Göreli referans çerçevesi açısından iki alan arasında bir fark saptanmazken içsel referans çerçevesi kullanımında iki alan arasında anlamlı bir fark tespit edilmiştir. Fen bilimlerinden gelen katılımcılar uygulama bütününde $59 \mathrm{kez}$ içsel referans çerçevesi kullanırken sosyal bilimlerden gelen katılımcılar 35 kez kullanmıştır. Bu da fen bilimlerinden gelen katılımcıların nesne-merkezli olan ve bilişsel dizgenin nesneleri temel parçalara bölmek zorunda olduğu içsel referans çerçevesini daha fazla kullanma eğiliminde olduklarına işaret etmektedir.

Çalışmada elde edilen veriler nesnelerin sahip oldukları özelliklerin, sahnedeki uzamsal düzenlenmelerin, taşıdıkları konumlanan ya da konumlayan 
rollerinin, uzamsal sahneyi ifade edecek bireyin algısının ve deneyimlerinin, sahnenin içinde bulunduğu durumsal bağlamın, kültürel özellikler gibi etkenlerin uzamsal referans çerçevesi seçimini etkilemekte olduğunu ortaya koymaktadır.

\section{Sonuç}

Türkçeyi gözlem nesnesi olarak ele aldığımızda uzamsal referans çerçeveleri açısından nasıl bir görünüm sergilediği sorusuna yanıt bulabilmek amacıyla yaptı̆̆ımız bu çalışmada, uygulamada yer alan dört farklı üretim görevini yerine getiren 80 katılımcının üretimlerinden elde edilen bulgular sonucunda Türkçede konumlanış aktarılırken hem göreli hem de içsel referans çerçevesinin kullanıldığı tespit edilmiştir. Her görevde iki referans çerçevesi de belirli oranlarda tercih edilmiştir. Buna karşın, mutlak referans çerçevesi kullanımına ilişkin herhangi bir bulguya erişilememiştir.

$\mathrm{Bu}$ çalı̧̧madan elde edilen bulgular ışı̆̆ında Türkçenin Tablo 1'deki (bkz. 2.3) diller arasındaki yerine baktığımızda baskın olarak göreli referans çerçevesi kullanıldığı, bunun yanında içsel referans çerçevesinin de belirli durumlarda kullanıldığı ve masa-üstü uzamda mutlak referans çerçevesinin kullanılmadığ1 sonucuna varabiliriz. Çalışmanın sınırlılıkları göz önünde bulundurulduğunda bu sonucun farklı konumlanan ve konumlayanlarla, farklı konumlanış ya da hareket ilişkileriyle, masa-üstü ya da coğrafi uzamda sınanması gerekmektedir.

Kuramsal Çerçeve başlığı altında ayrıntılı bir biçimde yer alan ve ilgili alanyazında ortaya koyulmuş olan referans çerçevesi seçiminde rol oynayan etkenler dikkate alınarak veritabanı üzerinde yapılan incelemeden elde ettiğimiz bulgular, Türkçeden bakıldığında uzamsal referans çerçevesi seçimindeki temel etkenlerin şu şekilde kendini gösterdiğini söyleyebilmemize veri oluşturmaktadır:

1. Konumlanan ile konumlayanın karakteristik özellikleri: İçsel yönlere sahip olup olmama, canlı ya da cansız olma, işlevsel özellikler.

2. Uzamsal sahneyi görüntüleyen kişiye göre konumlayanın yönelimi: Konumlayanın görüntüleyen kişiyle yüz yüze olması ya da yan durması.

3. Konumlananın konumlayana göre pozisyonu.

4. Uzamsal sahnenin sunuluş biçimi: Görüntüleyen kişi bu sahneyi bilgisayarda mı, büyük ekranda mı, gerçek dünyada mı görüyor?

Burada not etmek isteriz ki, bu çalışmada veri tabanımıza dayanarak Türkçenin penceresinden elde ettiğimiz görünüme göre cinsiyet referans çerçevesi seçiminde Türkçede bir değişken/etken değildir.

Katılımcılar fen bilimleri ve sosyal bilimler açısından değerlendirildiğinde göreli referans çerçevesi kullanımında bir fark gözlemlenmezken fen bilimlerinden gelen katılımcıların içsel referans çerçevesini daha fazla kullanma 
eğiliminde oldukları saptanmıştır. Bu sonuç, uzamsal referans çerçevelerinin farklı alanlar ya da farklı meslekler açısından denetlenmesi için temel dayanak olacaktır.

Göreli ve içsel referans çerçeveleri arasında anlam karmaşasının ortaya çıkmasının muhtemel bir durum olduğu ve olası karmaşanın engellenebilmesi için önerilen görüs açısının açıkça belirtilmesi (buradan, şurada vb.) ya da tümceyi sadece içsel olarak yorumlanacak biçimde düzenleme gereği konusunda alanyazında yapılmış öneriler anımsanacak olursa (bkz. 2.1 ve 2.2) bu çalışmada elde ettiğimiz referans çerçevesi tercihi ile ilgili sonuçlar Türkçede örneğin aşağıdaki gibi bir konumlandırmanın farklı okumalara neden imkan verdiğini de kendiliğinden açıklayabilmektedir:

- Kedi nerede?

- İçerde.

- Yok burada.

- Nereye bakiyorsun?

- Odaya. Dışarı bakacak halim yok ya!

- Evde tek bir oda yok ki...

O halde, Türkçe için konumlamada tercih edilen referans çerçevesinin içsel mi yoksa göreli mi olduğunu; olası anlam bulanıklığını ortadan kaldıracak belirginleştiricilerin örneğin eşdizimlilerin (collocations) olup olmadığı; ya da Türkçenin bulanıklığı engelleyen kurulumlar (constructions) sunup sunmadığı nesneler ve uzamda birbirlerine göre konumlanışları konusunda ileri çalışmalarla yanıtı aranması gereken sorular olacaktır.

\section{Kaynaklar}

Arık, E. (2003). Spatial representations in Turkish and sign language of Turkey (TID). Yayımlanmamış Yüksek Lisans Tezi. University of Amsterdam.

Beller, S., Singmann, H., Hüther L. \& Bender, A. (2015). Turn around to have a look? Spatial referencing in dorsal vs. frontal settings in cross-linguistic comparison. Frontiers in Psychology, 6: 1283, 1-17.

Borillo, A. (1998). L'espace et Son Expression en Français. Paris: Ophrys.

Brown, P., \& Levinson, S. C. (2000). Frames of spatial reference and their acquisition in Tenejapan Tzeltal. L. P. Nucci, G. B. Saxe, \& E. Turiel (Haz.) içinde, Culture, thought, and development (s. 167-197). New Jersey: Lawrence Erlbaum Associates.

Carlson, L.A. \& Hill, P.L. (2007). Experimental methods for studying language and space. M. Gonzalez-Marquez, I. Mittelberg, S. Coulson \& M.J. Spivey (Haz.) içinde, Methods in cognitive linguistics (s: 250-276). Amsterdam: John Benjamins Publishing Company. 
Carlson-Radvansky, L.A. \& Irwin, D. (1993). Frames of reference in vision and language: where is above? Cognition, 46, 223-244.

Carlson-Radvansky, L.A., \& Irwin, D.E. (1994). Reference frame activation during spatial term assignment. Journal of Memory and Language, 33, 646-671.

Carlson-Radvansky, L.A., \& Radvansky, G.A. (1996). The influence of functional relations on spatial term selection. Psychological Science, 7, 56-60.

Clark, H. (1973). Space, time, semantics and the child. T.E.Moore (Haz.) içinde, Cognitive development and the acquisition of language (s. 28-63). New York: Academic Press.

Cox, M.V. (1985). Deictic and Nondeictic Interpretations of 'in front of' and 'behind' in Fronted Object Tasks. International Journal of Behavioral Development, 8: 183-193.

Coventry, K.R. (1998). Spatial prepositions, functional relations, and lexical specification. P. Olivier \& K.-P. Gapp (Haz.) içinde, Representation and processing of spatial expressions (s. 247-262). Mahwah, NJ: Erlbaum.

Coventry, K.R., \& Prat-Sala, M. (1998). Geometry, function, and the comprehension of Over, Under, Above and Below. M.A. Gernsbacher \& S.J. Derry (Haz.) içinde, Proceedings of the Twentieth Annual Conference of the Cognitive Science Society (s. 261-266). Mahwah, NJ: Erlbaum.

Gallistel, C.R. (2002). Language and spatial frames of reference in mind and brain. Trends Cogn. Sci. 6, 321-322.

Haviland, J.B. (1993). Anchoring, iconicity, and orientation in Guugu Yimithirr pointing gestures. J. Linguist. Anthropol. 3, 3-45.

Haviland, J.B. (1998). Guugu Yimithirr cardinal directions. Ethos 26, 25-47.

Heine, B. (1997). Cognitive foundations of grammar. Oxford: Oxford University Press.

Herskovits, A. (1986). Language and spatial cognition: An interdisciplinary study of the prepositions of English. Cambridge, England: Cambridge University Press.

Herskovits, A. (1998). Schematization. P. Olivier \& K.-P. Gapp (Haz.) içinde, Representation and processing of spatial expressions (s. 149-162). Mahwah, NJ: Erlbaum.

Hill, C. (1982). Up/Down, Front/Back, Left/Right. A Contrastive Study of Hausa and English. J. Weissenborn and W. Klein (Haz.) içinde, Here and There. CrossLinguistic Studies on Deixis and Demonstration. Philadelphia: John Benjamins.

Imai, M., Nakanishi, T., Miyashita, H., Kidachi, Y. and Ishizaki, S. (1999). The Meanings of FRONT/BACK/LEFT/RIGHT. Cognitive Studies, 6, 207-225.

Johnston, J. ve Slobin, D. (1979). The development of locative expressions in English, Italian, Serbo-Croation, and Turkish. Journal of Child Language, 6, 529-45.

Landau, B., \& Jackendoff, R. (1993). "What" and "where" in spatial language and spatial cognition. Behavioral and Brain Sciences, 16, 217-238.

Levelt, W. J. M. (1984). Some perceptual limitations on talking about space. A. van Doom, W. van de Grind, and J. Koenderink (Haz.) içinde, Limits of perception: Essays in honour of Maarten A. Bouman (s. 323-358). Utrecht: VNU Science Press.

Levelt, W.J.M. (1989). Speaking: From intention to articulation. Cambridge, MA: MIT Press.

Levelt, W.J.M. (1996). Perspective taking and ellipsis in spatial descriptions, P. Bloom, M. Peterson,L. Nadel and M. Garrett (Haz.) içinde, Language and space (s. 77 -108). Cambridge, MA: MIT Press. 
Levinson, S.C. (1994). Vision, shape and linguistic description: Tzeltal body-part terminology and object description. Linguistics 32, 791-855.

Levinson, S.C., (1996). Frames of reference and Molyneux's question: crosslinguistic evidence. Bloom, P., Peterson, M., Nadel, L., Garrett, M. (Haz.) içinde, Language and Space (s. 109-170). Cambridge, MA: MIT Press.

Levinson, S.C. (2003). Space in language and cognition. Cambridge: Cambridge University Press.

Levinson, S.C. \& Wilkins, D.P. (Haz.) (2006). Grammars of space. Cambridge: Cambridge University Press.

Linn, M. C., Petersen, A. C. (1985). Emergence and Characterization of Sex Differences in Spatial Ability: A Meta-Analysis. Child Development. 56 (6): 1479-1498.

Majid, A., Bowerman, M., Kita, S., Haun, D., \& Levinson, S. (2004). Can language restructure cognition? The case for space. Trends in Cognitive Science, 8(3), 108-114.

Miller, G. A., \& Johnson-Laird, P. N. (1976). Language and Perception. Cambridge, England: Cambridge University Press.

Özyürek, A. (2000). Differences in spatial conceptualization in Turkish and English discourse: Evidence from both speech and gesture. A. Goksel, \& C. Kerslake (Haz.) içinde, Studies on Turkish and Turkic languages (s. 263-272). Wiesbaden: Harrassowitz.

Pederson, E., Danziger, E., Wilkins, D., Levinson, S., Kita, S., \& Senft, G. (1998). Semantic typology and spatial conceptualization. Language, 74(3), 557-589.

Pederson, E. (2003). How many reference frames? Freska, C. et al. (Haz.) içinde, Spatial Cognition III: Routes and Navigation, Human Memory and Learning, Spatial Representation and Spatial Learning (s. 287-304). Springer Verlag.

Piaget, J. (2011). Çocukta Akll Yürütme ve Karar Verme. (Çev: Sabri Esat Siyavuşgil), Ankara: Palme Yayıncilik

Retz-Schmidt, G. (1988). Various Views on Spatial Prepositions. AI Magazine, Vol. 9, No. 2, 95-105.

Shusterman, A. \& Li, P. (2016). Frames of reference in spatial language acquisition. Cognitive Psychology, 88, 115-16.

Sogo, E., Wada, Y. \& Kato, T. (2000). Selection of frame of reference in spatial cognition: Effects of the inherent direction of reference and located objects. Interdisciplinary Information Sciences, Vol. 6, No. 1, 13-21.

Sümer, B., Zwitserlood, I., Perniss, P. M., \& Özyürek, A. (2013). Acquisition of locative expressions in children learning Turkish Sign Language (TID) and Turkish. E. Arik (Haz.) içinde, Current directions in Turkish Sign Language research (s. 243-272). Newcastle upon Tyne: Cambridge Scholars Publishing.

Sümer, B., Zwitserlood, I., Perniss, P., \& Özyürek, A. (2016). Yer Bildiren İfadelerin Türkçe ve Türk İşaret Dili'nde (TID) Çocuklar Tarafından Edinimi. E. Arık (Haz.) içinde, Ellerle Konuşmak: Türk İşaret Dili Araştırmaları (s. 157-182). İstanbul: Koç Üniversitesi Yayınları.

Svorou, S. (1994). The grammar of space. Philadelphia, PA: John Benjamins.

Taylor, H.A., \& Tversky, B. (1992). Descriptions and depictions of environments. Memory and Cognition, 20, 483-496. 
Tversky, B. (1991) Spatial mental models. G. H. Bower (Haz.) içinde, The psychology of learning and motivation: Advances in research and theory, vol. 27 (s. 109-146). New York: Academic Press.

Vandeloise, C. (1986). L'espace en français: semantique des prepositions spatiales. Paris: Le Seuil.

Vandeloise, C. (1994). Methodology and analyses of the preposition in. Cognitive Linguistics, 5, 157-184.

Weiss, E. M., Kemmler, G., Deisenhammer, E. A., Fleischhacker, W.W., Delazer, M. (2003). Sex differences in cognitive functions. Personality and Individual Differences. 35 (4): 863-875. 